Monetary Policy in Low Income Countries in the Face of the Global Crisis: The Case of Zambia

Alfredo Baldini, Jaromir Benes, Andrew Berg, Mai C. Dao, Rafael Portillo 
IMF Working Paper

Research Department and African Department

\title{
Monetary Policy in Low Income Countries in the Face of the Global Crisis: The Case of Zambia *
}

\author{
Prepared by Alfredo Baldini, Jaromir Benes, Andrew Berg, Mai C. Dao, Rafael Portillo \\ Authorized for distribution by Andrew Berg and George Tsibouris
}

\$ SUO2012

\section{This Working Paper should not be reported as representing the views of the IMF.} The views expressed in this Working Paper are those of the author(s) and do not necessarily represent those of the IMF or IMF policy, or of DFID. Working Papers describe research in progress by the author(s) and are published to elicit comments and to further debate.

\begin{abstract}
We develop a DSGE model with a banking sector to analyze the impact of the financial crisis on Zambia and the role of the monetary policy response. We view the crisis as a combination of three related shocks: a worsening in the terms of the trade, an increase in the country's risk premium, and a decrease in the risk appetite of local banks. We characterize monetary policy as "stop and go": initially tight, subsequently loose. Simulations of the model broadly match the path of the economy during this period. We find that the initial policy response contributed to the domestic impact of the crisis by further tightening financial conditions. We study the factors driving the "stop" part of policy and derive policy implications for central banks in low-income countries.
\end{abstract}

JEL Classification Numbers:E5, F32, F37

Keywords: Global Financial Crisis, Low-Income Countries, Monetary Policy, Zambia

Author's E-Mail Address: abaldini@imf.org, jbenes@,imf.org, aberg@,imf.org, mdao@,imf.org, rportillo@,imf.org

\footnotetext{
* This working paper is part of a research project on macroeconomic policy in low-income countries supported by the U.K.'s Department for International Development.
} 


\section{Contents}

Page

I Introduction ........................ 4

II Core model structure . . . . . . . . . . . . . . . . . . 7

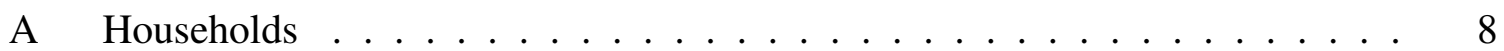

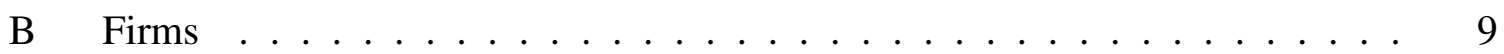

$1 \quad$ Domestic Firms . . . . . . . . . . . . . . . . . 9

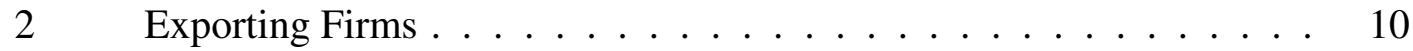

C The Banking Sector . . . . . . . . . . . . . . . . . . 11

D Monetary Authority . . . . . . . . . . . . . . . . 12

E The Government . . . . . . . . . . . . . . . . . . . . . . . . . . . . . . . .

F Relationship with the Rest of the World . . . . . . . . . . . . . . 14

III Applying the model to Zambia . . . . . . . . . . . . . . . . . . . . . . 14

A The Zambia data set . . . . . . . . . . . . . . . . . . 15

B Calibration and functional forms . . . . . . . . . . . . . . 15

C Overview of shocks and the transmission mechanism . . . . . . . . . . 17

D Replicating the crisis . . . . . . . . . . . . . . . . . . 18

E Baseline results ............................. 19

F Shock decomposition ........................ 20

G The role of the monetary policy response: shock counterfactuals . . . . . . 22

$\mathrm{H}$ The role of the monetary policy response: rule counterfactuals . . . . . . 23

IV Understanding the initial monetary policy response . . . . . . . . . . . 23

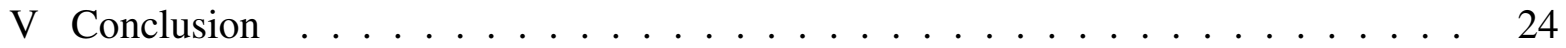

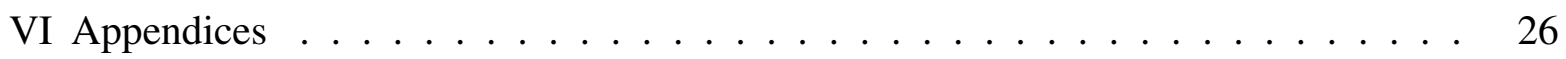

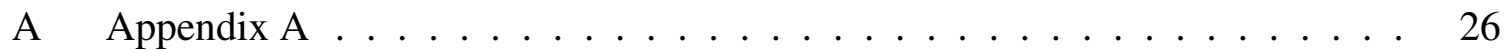

$1 \quad$ Notational conventions . . . . . . . . . . . . 26

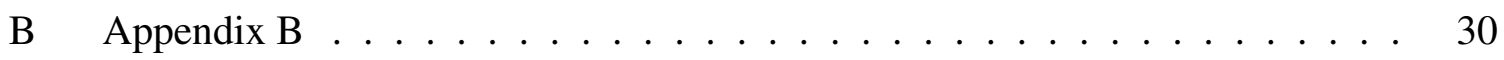

Tables

1 Calibration of model parameters and steady-state ratios . . . . . . . . . . . 34

2 Model performance across alternative monetary policy responses . . . . . . . . 35

3 Money targets in Zambia, 2008-2009, in bn of Kwacha. . . . . . . . . . . . 35

Figures

1 Model blocks ........................... 36

2 Impulse response functions of key variables to a terms of trade shock and a monetary policy shock. . . . . . . . . . . . . . 37 
3 Impulse response functions of key variables to a risk premium shock and a banking shock. . . . . . . . . . . . . . . . . . . . . 38

4 Overview of the baseline simulation . . . . . . . . . . . . . . . . . 39

5 Tuned paths of external shocks. . . . . . . . . . . . . . . . . . 40 40

6 Structural shock decomposition $1 . \ldots \ldots \ldots \ldots$. . . . . . . . . . . . 41

7 Structural shock decomposition $2 \ldots \ldots \ldots \ldots$. . . . . . . . . . . 42

8 Structural shock decomposition: monetary variables. . . . . . . . . . . . . 43

9 Counter-factual simulation 1: flat money growth. . . . . . . . . . . . . 44

10 Counter-factual simulation 2: expansionary policy. . . . . . . . . . . . . 45

11 Key monetary variables prior to and during the crisis. . . . . . . . . . . . . . 46 


\section{INTRODUCTION}

Understanding the impact of the global financial crisis in low-income countries (LICs) is an important task for national authorities and international organizations. Beyond its intrinsic importance, the crisis provides a relatively clean "experiment": it can be interpreted as an exogenous event for most LICs, while its magnitude facilitates tracing its effects. As such, it provides insights about the structure of these economies and their exposure to external factors. It also allows central banks to assess—and learn from—past decisions.

Central banks in developed and emerging markets make ample use of both small and large quantitative structural models for this kind of exercise. ${ }^{2}$ These models have proven useful for studying shocks and monetary policy; they are not meant to provide the ultimate answer, but rather to structure thinking and organize the evidence. The use of such models remains fairly limited in low-income countries, however, for several reasons. First, many of these countries have only recently emerged from prolonged periods of fiscal dominance and chronic inflation, and monetary policy was primarily focused in re-anchoring inflationary expectations rather than stabilizing economic activity. ${ }^{3}$ Second, it is still an open question whether these models are useful for LICs. As several authors have pointed out, the monetary transmission mechanism is considered very different in these countries: a large fraction of the population does not have access to financial services, banks dominate the financial system, secondary markets for government securities are often missing, and interest rates may not reflect domestic financial conditions. ${ }^{4}$ Third, many of the standard models do not explicitly incorporate various monetary aggregates, which typically serve as operational and intermediate targets in LICs' monetary policy frameworks. ${ }^{5}$

This paper provides a first attempt at filling this gap. We develop a quantitative model - adapted to the specific characteristics of LICs - to analyze the impact of the financial crisis on Zambia, and the role that monetary policy played in the transmission of the crisis. We compare the predictions of the model to a data set of Zambian macroeconomic and financial variables.

Zambia is in many ways a representative low-income country. It is dependent on commodity exports (copper). It is financially underdeveloped, with foreign-owned banks playing the central role, along with the exchange rate, in the transmission of monetary policy. Its monetary policy framework is also fairly representative. The Bank of Zambia targets monetary aggregates under a floating exchange rate regime. As in other LICs, fiscal

\footnotetext{
${ }^{2}$ Notable examples of large models include the SYGMA model developed at the Board of the Governors of the Federal Reserve (Erceg, Guerrieri and Gust (2006), the GEM and GIMF models developed at the IMF (Laxton and Pesenti (2003) and Kumhoff and others (2010)) and the BEQM model developed at the Bank of England (Harrison and others, (2003)). Smaller models include the FPAS framework described in Berg, Karam and Laxton (2006).

${ }^{3}$ See Adam and O'Connell (2006).

${ }^{4}$ See IMF (2008) and Mishra and others (2010).

${ }^{5}$ See Berg, Portillo and Unsal (2010).
} 
developments can pose a challenge for monetary policy through their effect on aggregate demand and the allocation of credit.

The design of our model explicitly incorporates these features. We model banks' various assets and liabilities and their respective interest rates, and assume that the private sector is unable to obtain financing beyond the banking system. We allow for the possibility that shocks to the banking system may be reflected in binding credit constraints in addition to higher interest rates. We also model fiscal developments and their implications for the transmission of external shocks. Our model is otherwise standard, i.e., it conforms to the typical structure of DSGEs. ${ }^{6}$

From Zambia's perspective-and that of low-income countries in general-we view the global financial crisis in terms of three related shocks. The first was a large deterioration in Zambia's terms of trade, associated with the collapse in copper prices during 2008 and 2009. The second was an increase in the country's external risk premium, as foreign investors' demand for Zambian assets decreased. The third shock was a decrease in Zambian banks' risk appetite in response to the crisis. Banks increased lending rates, reduced their lending to the domestic private sector, and increased their demand for liquidity and government bonds. We view these shocks as reflecting a single underlying event—-the global financial crisis - though we do not undertake here to model this relationship.

The combination of these shocks led to a large nominal and real depreciation, a reversal in current account dynamics - from large deficits to balance - a decline in domestic demand, and a temporary decrease in inflationary pressures. On the fiscal front, government revenues declined and debt issuance increased. In the banking sector, the reallocation of assets away from loans to the private sector and toward government securities and liquidity, together with a steep slowdown in the growth of broad money, contributed to a decrease in the money multiplier (or alternatively, an increase in measures of banks' liquidity).

In this context, the actual response of monetary policy can be characterized as "stop and go". The T-bill rate (the preferred instrument for open market operations in Zambia) initially increased by 400 basis points between mid 2008 and mid 2009. As the crisis propagated, the policy stance was later reversed, allowing T-bill rates to fall by more than 1000 basis points in the second half of 2009, and liquidity increased substantially.

We reproduce the crisis in our model by picking a combination of the aforementioned shocks that help match the exact path of key external variables (the terms of trade, the nominal exchange rate and the current account). ${ }^{7}$ We then compare the model's output with data on

\footnotetext{
${ }^{6}$ By typical structure we mean that profit and utility maximization by agents in the model result in equations that are standard in DSGEs: new-Keynesian Phillips curves for prices and wages-with both forward- and backward-looking elements - an Euler equation for consumption, various factor demand functions by firms and interest parity conditions between domestic and foreign assets. In addition the economy is subject to a resource constraint (the balance of payments).

${ }^{7}$ We simulate our model using IRIS, a Matlab-based package developed by one of our coauthors (Jaromir Benes). This package is ideally suited for confronting DSGE models with data and for operating policy analysis and forecasting systems organized around such models. It can be freely downloaded from www.iristoolbox.org.
} 
ten macroeconomic and financial variables, conditional on the "stop and go" policy pattern, i.e., on a sequence of monetary policy shocks that replicates the large swings in T-bill rates.

Our main results are the following. First, we find that the model broadly reproduces the path of most variables, with the notable exception of GDP. This relative success increases our confidence that DSGE models can contribute to the quantitative analysis of macroeconomic developments and policy in Zambia and low-income countries more generally, although more work is needed to understand the behavior of GDP and the macro-financial-balance of payment linkages in these countries.

Second, we find that all three real shocks - terms of trade, external risk premium and change in banks' appetite for risk - are necessary to help match the data. The first two shocks tend to generate the desired nominal depreciation and a subsequent decrease in imports but they have counterfactual implications for the current account and the volume of credit, as consumers would smooth the temporary decrease in income through an increase in externally financed credit and a higher current account deficit. Meanwhile, the decrease in banks' risk appetite helps match the current account reversal and the contraction in credit but by itself would result in a appreciation of the currency, as relative demand for foreign goods would decrease. It is only by combining the three shocks that the model can reproduce the stylized facts.

Third, our modeling exercise shows that developments in the banking sector were an important part of the transmission of the crisis to the domestic economy. In our model, the contraction in credit induced by banks is required to generate the right current account reversal, while its impact on aggregate demand helps generate the decline in inflation observed during the crisis. The increase in lending premia is also helpful to understand the impact on aggregate demand, although by itself it would not generate a current account reversal. Moreover, banks demand for liquid and safe assets helped shape the monetary policy stance, given the money-targeting regime in place.

Finally, our model shows that the "stop and go" policy response was counterproductive, in that it may have contributed initially to the contraction in aggregate demand. A more accommodating policy would have helped stabilize the economy earlier, albeit at the cost of higher nominal depreciation and inflation. While the effect would have been limited in absolute terms, given the magnitude of the real shocks hitting the economy, such a policy would have reduced the decline in private spending in 2009 by 3 to 6 percent, depending on the specification. Policy rules that respond to various developments in the banking system (changes in the growth rate of credit or deposits) would have also helped stabilized the economy.

In light of the last result, we also discuss the determinants of the initial "stop" response of monetary policy. We find that the policy response appears to have been driven by "rear-view" or "side-view" issues, not all of them directly related to the crisis. First, authorities were concerned with inflationary pressures at the time, mostly associated with the food and fuel price shock of 2007 and early 2008. Second, authorities may have also been responding to the large nominal depreciation induced by the crisis. Third, authorities may have been reluctant to loosen policy at a time of incipient increases in measures of "excess liquidity". 
Policy makers were also likely influenced by the overshooting of reserve money targets during 2008, which may have led to a view that monetary policy was loose.

Our paper is related to the large and growing literature on the impact of the recent financial crisis. ${ }^{8}$ Relative to previous work on the credit channel, which focused on the role of borrowers' financial conditions on the amplification of shocks, recent work has emphasized developments in the financial system itself as the source of the crisis. ${ }^{9}$ Our work has elements of both, giving importance to both systemic and counterparty-specific risks. Unlike most of these recent contributions however, we limit ourselves to a relatively simple treatment of the banking sector in an open economy, since our goal is to provide a coherent story for Zambia's experience during the crisis.

Our paper is also related to the literature on financial crises in emerging markets, especially on the role of monetary policy. ${ }^{10}$ We differ in that our focus is on a combination of external shocks - rather than just the current account reversal - and we pay special attention to developments in the banking/monetary system. Also, the relatively low degree of financial dollarization in Zambia (less than 30 percent of loans and deposits) allows us to abstract from currency mismatches - a central theme in that literature. Finally, our work is also related to Agenor and Montiel (2006, 2007) who emphasize_-in a static small open economy framework - the role of the domestic banking system in monetary policy in developing countries.

The paper is organized as follows. Section II introduces the structure of the model and the shocks we consider. Section III discusses the Zambia data and the calibration, and applies the model to Zambia under the actual path of monetary policy and under alternative policy responses. Section IV discusses the factors behind the initial monetary policy response. Section V derives some policy implications for low income countries and concludes.

\section{CORE MODEL STRUCTURE}

The model is made up of the following six blocks: households, firms, the banking system, the monetary authority, the government, and the rest of the world. The flow chart in Figure 1 visualizes the links and feedback relations between these blocks.

\footnotetext{
${ }^{8}$ Papers on the overall impact of the crisis in low-income counties include IMF (2009b) and Berg and others (2010).

${ }^{9}$ The former literature was built on the seminal contributions of Bernanke, Gertler and Gilchrist (1999) and Kiyotaki and Moore (1997). New work on financial intermediation includes Goodfriend and McCallum (2007), Christiano, Motto and Rostagno (2009), Curdia and Woodford (2009), Adrian and Shin (2010) and Gertler and Kiyotaki (2010). See Woodford (2010) for a simple exposition.

${ }^{10}$ The seminal paper is by Calvo (1998). Other contributions include Aghion, Bachetta and Banerjee (2001), Christiano, Gust, and Roldos (2004), Chari, Kehoe and McGrattan (2005), Mendoza (2006), Calvo, Izquierdo and Talvi (2006), among many others.
} 
For each block we present the equations that describe behavior. See appendix A for a derivation from utility and profit maximization. Note that in some cases we relax some of the restrictions imposed by optimization to allow for greater flexibility in the dynamics of the model. This greater flexibility helps match the specific path of real macro and financial variables during the crisis, without forsaking the logic of first principles or diluting the mechanisms of interest. ${ }^{11}$

\section{A. Households}

Our modeling of households has the following features. First, households' intertemporal decisions are influenced by the domestic lending rate $\left(R_{t}^{L}\right)$, reflecting the dominance of banks in financial systems in LICs. Second, consumers may be constrained in their ability to borrow at the lending rate offered by banks. These features are reflected in our Euler equation for consumption:

$$
\lambda_{t}=E_{t}\left[\lambda_{t+1} \frac{\beta R_{L, t}}{\pi_{c, t+1}}\right]+u_{F, 1, t},
$$

where $\pi_{c, t}$ is CPI inflation, $\lambda_{t}$ is the marginal value of wealth, and $u_{F, 1, t}$ is the value of the multiplier associated with the borrowing constraint. ${ }^{12}$ The marginal value of consumption is given by:

$$
\lambda_{t}=\frac{1}{\left(C_{t}-\chi C_{t-1}\right)}
$$

The parameter $\chi$ measures the degree of backward-looking behavior (or habit formation). We assume total consumption is spent on domestic goods and imports following a Leontieff specification, which implies the following demand for domestic goods: $C_{d, t}=\omega C_{t}$. This specification captures the view that in low-income countries imports are not close substitutes with domestically-produced goods. The CPI is a weighted sum of import and domestic prices: $P_{c, t}=\omega P_{d, t}+(1-\omega) P_{M, t}$. The demand for imports is also potentially affected by a borrowing constraint:

$$
C_{M, t}=(1-\omega) C_{t}-u_{F, 2, t},
$$

with $u_{F, 2, t}$ denoting the marginal value of the constraint. ${ }^{13}$ This restriction allows us to emphasize the impact of a financial shock on the demand for imports rather than on overall consumption (more on this below). Financing for import consumption requires lenders'

\footnotetext{
${ }^{11}$ See Erceg, Guerrieri and Gust (2005) for a discussion of the restrictions implied by fully micro-founded models and their implications for matching short-run properties of the data.

${ }^{12}$ See Mendoza (2006).

${ }^{13}$ This constraint can be microfounded by assuming that consumers pay for imports at the beginning of the period, before receiving their labor and interest income, and that such lending is subject to a borrowing constraint that may fluctuate over time. While the rate at which consumers borrow within the period would also show up in the consumer price index, we assume such rate is equal to zero.
} 
acceptance of additional foreign currency exposure. It is plausible that banks may be especially unwilling to finance such exposure during the crisis. ${ }^{14}$

Consumers demand deposits from banks, which earn interest at the rate $R_{D, t}$. The demand for real deposits is given implicitly by the following function:

$$
\frac{R_{L, t}}{R_{D, t}}=D\left(C_{t}, C_{t-1}, \frac{D_{t}}{P_{c, t}}\right)
$$

where $D\left({ }^{*},{ }^{*},{ }^{*}\right)$ is continuously differentiable and homogeneous of order zero, with $D_{i}>0$ for $i=1,2$ and $D_{3}<0$. Demand for real deposits depends on consumption and the ratio of lending rates and deposit rates; lagged consumption is introduced to generate sluggishness in the demand for deposits.

The supply of labor by consumers is subject to nominal wage rigidities. This results in a Phillips curve for nominal wage inflation $\left(\pi_{W, t}=\frac{W_{t}}{W_{t-1}}\right)$, which depends on future and past wage growth and deviations between the marginal disutility of labor-which is constant—and the marginal value of real wages:

$$
\log \left(\frac{\pi_{W, t}}{\pi_{W, t-1}}\right)=\beta \log \left(\frac{\pi_{W, t+1}}{\pi_{W, t}}\right)+\xi_{w}\left(\frac{1}{\frac{W_{t}}{P_{c, t}} \lambda_{t}}-1\right) .
$$

\section{B. Firms}

There are two types of firms in the economy: those that produce for domestic consumption and firms that produce export goods for the world market.

\section{Domestic Firms}

Domestic firms produce consumption goods using labor, capital—-the stock of which has been fixed to 1 -and imported inputs $M_{Y, t}$ :

$$
Y_{t}=N_{Y, t}^{\gamma_{N}} M_{Y, t}^{\gamma_{M}}
$$

Cost minimization leads to the following equations for factor demand:

$$
\gamma_{N} P_{Y, t} Y_{t}=W_{t} N_{Y, t} F\left(\frac{N_{Y, t}}{M_{Y, t}}, \frac{N_{Y, t-1}}{M_{Y, t-1}}, \frac{N_{Y, t+1}}{M_{Y, t+1}}\right),
$$

\footnotetext{
${ }^{14}$ We do not model issues related to currency risk. Efforts to microfound this risk might be instructive but are outside the scope of this paper.
} 


$$
\begin{gathered}
\gamma_{M} P_{Y, t} Y_{t}=P_{M, t} M_{Y, t} F\left(\frac{N_{Y, t}}{M_{Y, t}}, \frac{N_{Y, t-1}}{M_{Y, t-1}}, \frac{N_{Y, t+1}}{M_{Y, t+1}}\right), \\
\left(1-\gamma_{N}-\gamma_{M}\right) P_{Y, t} Y_{t}=Q_{t},
\end{gathered}
$$

where $W_{t}, P_{M, t}, Q_{t}$ are factor costs and $P_{Y, t}$ is the sector's nominal marginal cost. The function $F()$ introduces sluggish adjustment in the demand for labor and imported inputs in response to changes in (relative) factor prices; it is introduced to improve the empirical properties of the model.

Domestic inflation $\pi_{d, t}=\frac{P_{d, t}}{P_{d, t-1}}$ is given by a hybrid Phillips curve:

$$
\log \left(\frac{\pi_{d, t}}{\pi_{d, t-1}}\right)=\beta \log \left(\frac{\pi_{d, t+1}}{\pi_{d, t}}\right)+\xi_{c}\left(\frac{P_{Y, t}}{P_{d, t}}-1\right) .
$$

Finally, the nominal value of capital $P_{K, t}$, which as we will see later matters for risk premia in the banking sector, is given by a standard forward-looking asset pricing equation:

$$
P_{K, t}=\sigma_{K}\left(\frac{1}{R_{L, t}}\left(Q_{t+1}+(1-\delta) P_{K, t+1}\right)\right)+\left(1-\sigma_{K}\right) P_{K, t-1},
$$

where $\delta$ is the depreciation rate for physical capital and $\sigma_{K}$ is the degree of forward-looking behavior in the pricing of capital.

\section{Exporting Firms}

Exporting firms use domestic and imported inputs. They take prices for their output as given by world markets $\left(P_{X, t}\right)$. Supply of exports is given by the ratio between the price of exports and the marginal cost of firms in that sector, subject to adjustment costs:

$$
\frac{P_{x, t}}{\alpha P_{Y, t}+(1-\alpha) P_{m, t}}=1+\psi_{X} \log \left(\frac{X_{t}}{X_{t-1}}\right)-\beta \psi_{X} \log \left(\frac{X_{t+1}}{X_{t}}\right),
$$

where $\alpha$ is the share of domestic goods in the production of traded goods. This parsimonious specification helps capture a low elasticity of exports to relative prices, given an inelastic supply of factors and limited mobility across sectors. The price of exports $P_{X, t}$ is subject to shocks to the terms of trade $T_{t}$ :

$$
P_{x, t}=P_{M, t} T_{t}=S_{t} P_{w, t} T_{t}, \ln T_{t}=\ln T_{t-1}+u_{T, t},
$$

where $\mathrm{S}$ is the nominal exchange rate. 


\section{The Banking Sector}

We assume financial intermediation is carried out by a perfectly competitive banking system, which consists of wholesale and retail branches. At the wholesale level the representative bank's balance sheet is the following:

$$
L_{t}+H_{t}+B_{b k, t}=D_{t}+F_{t}
$$

Banks' liabilities consist of deposits by residents $D_{t}$ and foreign debt $F_{t}$-denominated in foreign currency but measured here in local currency. Assets consist of loans $L_{t}$, government bonds $B_{b k, t}$, and reserves at the central bank $H_{t}$, which earn no interest but help banks manage liquidity needs associated with deposits.

Profit maximization by banks lead to several arbitrage conditions. First, arbitrage between local currency returns on domestic and foreign bonds, $R_{B, t}$ and $R_{t}$, respectively, lead to the following relation:

$$
R_{B, t}=R_{t},
$$

where $R_{t}$ is given by the uncovered interest parity with world interest rates plus a potential shock to the country risk premium:

$$
R_{t}=R_{t}^{*} E_{t}\left[\frac{S_{t+1}}{S_{t}}\right]+u_{R, t}
$$

Arbitrage between (net) returns on loans and other assets lead to the following relation between wholesale lending rates $R_{L, t}^{*}$ and interest rates on government bonds:

$$
R_{L, t}^{*}=R_{B, t}+u_{F, 3, t}
$$

where we have included an exogenous component to the risk premium on loans $\left(u_{F, 3, t}\right)$. Note that wholesale lending rates are not directly relevant for private sector decisions.

Finally, liquidity needs to manage deposit results in the following implicit demand for $H$ :

$$
R_{B, t}=H\left(D_{t}, H_{t}\right)+u_{F, 4, t},
$$

where $H\left({ }^{*},{ }^{*}\right)$ is continuously differentiable and homogeneous of degree zero, with $H_{1}>0$ and $H_{2}<0$. Banks demand for liquidity is also subject to a shock $u_{F, 4, t}$. As a result of these liquidity needs there is a negative premium on the interest rate on deposits:

$$
R_{D, t}=R_{t}-\Lambda\left(\frac{D_{t}}{H_{t}}\right),
$$

with $\Lambda_{1}<0$.

At the retail level, branches receive funding from wholesale branches and extend credit to households with some degree of monopoly power. Retail lending is risky and rates are 
subject to adjustment costs, all of which results in the following pricing equation for loans:

$$
\log \left(R_{L, t} / R_{L, t-1}\right)=\beta \log \left(R_{L, t+1} / R_{L, t}\right)+\xi_{R} \log \left(R_{L, t}\left(1-g_{t}\right) / R_{L, t}^{*}\right)
$$

where $g_{t}$ is given by:

$$
g_{t}=g_{1}\left(\frac{R_{L, t} L_{t}}{E_{t}\left[P_{k, t+1}\right]}-\frac{R_{L}^{-} L}{\bar{P}_{k}}\right),
$$

and a $(\bar{*})$ on top of a variable denotes its steady state value. Three factors affect the risk premium on lending rates. The first factor is the external finance premium $g_{t}$. It is usually micro-founded by assuming that returns on loans are risky, reflecting idiosyncratic risk on the borrowers part, which is costly for banks to verify and requires a compensating premium. This informational asymmetry is greatly reduced if borrowers can provide their own funds (capital in this case) to finance part of their project, which is why lowering the ratio of gross repayments to the value of capital reduces the premium. The second factor is the exogenous component $u_{F, 3, t}$ in equation (16). Finally the dynamic path of the lending rate is also affected by the adjustment costs at the retail level.

Beyond the arbitrage conditions between different interest rates, we also allow for the possibility that banks may ration borrowers at the prevailing lending rate. The rationing is captured by the shocks $u_{F, 1, t}$ and $u_{F, 2, t}$. While we do not model the rationing formally, we believe there are reasons why banks may be reluctant to raise interest rates sufficiently to eliminate excess demand for loans, either because of adverse selection (as in Stiglitz and Weiss (1983), costly state verification (as in Williamson (1987)) or moral hazard (as in Bester and Hellwig (1987)).

We model a decrease in banks' appetite for risk as a simultaneous increase in shocks $u_{F, i, t}$, for $\mathrm{i}=1, \ldots, 4$. As a result of higher aversion, banks simultaneously increase the premium on lending rates $\left(u_{F, 3, t}\right.$ in equation (16)), ration their lending to the domestic private sector, including import finance (shocks $u_{F, 1, t}$ and $u_{F, 2, t}$ in equations (1) and (2), respectively) and increase their demand for liquidity $\left(u_{F, 4, t}\right.$ in equation (17)). This simultaneity justifies treating these proximate shocks as coming from one single shock-the increase in banks' appetite for risk, which we denote $u_{F, t}$. We impose the following normalization:

$$
u_{F, 1, t}=u_{F, t} ; u_{F, 2, t}=\mu_{2} u_{F, t} ; u_{F, 3, t}=\mu_{3} u_{F, t} ; u_{F, 4, t}=\mu_{4} u_{F, t},
$$

where the $\mu_{i} \mathrm{~s}$ are chosen to improve the fit of the model.

\section{Monetary Authority}

We allow for different options regarding how the monetary authority operates, i.e., what variables are targeted by the central bank, and what instruments-or combinations of instruments-are used. We allow for such flexibility in this block of the model in order to help account for systematic differences between policy choices in LICs and advanced economies, and to compare among various policy rules. 
Here are the policy rules we model:

- A reserve money growth rule:

$$
\frac{H_{t}}{H_{t-1}}=1-\kappa_{\pi, H}\left(\pi_{c, t+1}-1\right)-\kappa_{D, H}\left(\frac{D_{t}}{D_{t-1}}-1\right)-\kappa_{L, H}\left(\frac{L_{t}}{L_{t-1}}-1\right)-u_{M, t}
$$

The reserve money growth rule nests various specifications: (i) an inflation targeting regime implemented using reserve money growth as the policy instrument $\left(\kappa_{D, H}=\kappa_{L, H}=0, \kappa_{\pi, H}>0\right)$; (ii) a constant money growth rule $\left(\kappa_{D, H}=\kappa_{L, H}=\kappa_{\pi, H}=0\right)$; (iii) a rule that combines inflation targeting with broad money targeting $\left(\kappa_{D, H}>0\right.$, $\left.\kappa_{\pi, H}>0\right)$; (iv) a rule that targets credit growth $\left(\kappa_{L, H}>0\right)$. Note that rule (iii) is consistent with current practice in some LICs, where broad money is often an intermediate target whereas reserve money serves as an operational target.

- Standard Taylor rule with the interest rate on government bonds being the main policy instrument:

$$
R_{B, t}=\rho_{R} R_{B, t-1}+\left(1-\rho_{R}\right)\left(\bar{R}_{B}+\kappa_{\pi}\left(\pi_{c, t+1}-1\right)\right)+u_{M, t}
$$

Note that in both of types of rules we abstract from targeting the output gap since this variable is difficult to assess in low-income countries, with quarterly GDP often unavailable. Without loss of generality, our policy rules imply a zero inflation target: when comparing the model with the data we add a constant term-reflecting the authority's implicit inflation target - to the inflation dynamics of the model. Depending on the rule, a tightening of monetary policy can be modeled as a positive shock $u_{M, t}$ to the policy rate/short term T-bill rate $R_{B, t}$ or a liquidity withdrawal $-u_{M, t}$ on $H_{t}$.

We also keep track of the central bank balance sheet:

$$
B_{c b, t}=H_{t}+F_{t}
$$

where $B_{c b, t}$ denotes the central bank's holdings of government debt and $F_{t}$ are the central bank's international reserves (measured in local currency). In this paper we set $F_{t}$ to zero, since intervention in the foreign exchange market did not play an important role in Zambia during the global crisis. Regardless of the policy regime, we assume the central bank implements policy by varying $B_{c b, t}$. Finally we define a measure of relative or "excess" liquidity in the banking system, which is given by the inverse of the money multiplier:

$$
E L_{t}=\frac{H_{t}}{D_{t}}
$$

\section{E. The Government}

The government taxes economic agents, spends on a basket of goods similar to consumers', issues debt, and pays interest. Its budget constraint is given by:

$$
P_{c, t} G_{t}=T_{t}+B_{t}-B_{t-1}-R_{B, t-1} B_{b k, t},
$$


where $G_{t}$ is real government spending, $T_{t}$ is the nominal tax revenue and $B_{t}$ is the total stock of government debt $\left(B_{t}=B_{b k, t}+B_{c b, t}\right)$. We assume the government only pays interest on debt held by commercial banks. Consistent with the tax structure in many low-income countries, where import duties make a large share of government revenue, we assume that tax revenue (in percent of nominal GDP) is sensitive to the value of imports:

$$
\frac{T_{t}}{Y_{t}^{N}}=\frac{T}{Y^{N}}+\phi\left(\frac{P_{M, t} M_{t}}{Y_{t}^{N}}-\frac{P_{M} M}{Y^{N}}\right)
$$

$Y_{t}^{N}$ is the level of nominal GDP and $\phi$ measures the sensitivity of tax revenues to imports.

Government debt is anchored by the following spending rule:

$$
\frac{P_{c, t} G_{t}}{Y_{t}^{N}}=\rho_{G} \frac{P_{c, t-1} G_{t-1}}{Y_{t-1}^{N}}+\left(1-\rho_{G}\right)\left(\frac{P_{c} G}{Y^{N}}-\tau_{G}\left(\frac{B_{b k, t}}{Y_{t}^{N}}-\frac{B_{b k}}{Y^{N}}\right)\right)
$$

This rule ensures that government debt outstanding converges to a given long run level $\frac{B^{b k}}{Y^{N}}$. The parameter $\rho_{G}$ measures the sluggishness in real government spending (in percent of GDP), while $\tau_{G}$ - together with $\rho_{G}$-measures the speed of adjustment to reduce debt levels. ${ }^{15}$

Note that the country's resource constraint requires $Y_{t}=X_{t}+C_{d, t}+\omega G_{t}$, while nominal GDP is defined as $Y_{t}^{N}=P_{c, t}\left(C_{d, t}+G_{t}\right)+P_{X, t} X_{t}-P_{M, t} M_{t}\left(\right.$ with $\left.M_{t}=C_{M, t}+M_{Y, t}+(1-\omega) G_{t}\right)$.

\section{F. Relationship with the Rest of the World}

We close our model by keeping track of the country's balance of payments:

$$
F_{t}=R_{t-1}^{*} \frac{S_{t}}{S_{t-1}} F_{t-1}-\left(P_{x, t} X_{t}-P_{M, t} M_{t}\right) .
$$

\section{APPLYING THE MODEL TO ZAMBiA}

Having introduced the core structure of the model, we now apply it to Zambia. In this section we discuss the data, calibration, the characterization of the crisis, and the simulation results.

\footnotetext{
${ }^{15}$ Our modeling of fiscal and monetary policy assumes lack of fiscal dominance, i.e., monetary policy is active while fiscal policy is passive. See Baldini and Poplawski-Ribeiro (2011) for an assessment of fiscal dominance in sub-Saharan Africa.
} 


\section{A. The Zambia data set}

We collected data for 15 quarterly macroeconomic and financial variables. ${ }^{16}$ On the external sector the data includes the terms of trade, imports, the current account, and the nominal exchange rate. Data on the banking/monetary sector includes reserve and broad money, credit to the private sector by the banking system, interest rates on treasury bills, and lending rates. As in our model, we use the ratio of reserve money to broad money to assess liquidity in the banking sector, rather than the measure of liquidity used by the authorities-banks' reserves in excess of those needed to satisfy regulatory requirements. ${ }^{17}$ On the fiscal side, we collected data on total revenues, spending and the stock of government debt. On the real sector side, we have quarterly data on GDP, interpolated from annual data.

We present the data as follows. About half of the variables (terms of trade, real credit to the private and public sector, real imports, real GDP growth, and excess liquidity) are expressed as percentage deviations from a deterministic trend or constant, which we calculate using pre-crisis data for each variable. Nominal variables are expressed in percentage points-Zambia's inflation target during this period is assumed to be 10 percent. Finally, to help understand the magnitude of the macroeconomic adjustment, government revenues, government spending, and the current account are measured in percent of GDP.

\section{B. Calibration and functional forms}

Simulating the model requires specifying functional forms for functions $\mathrm{D}, \mathrm{F}, \mathrm{H}$ and $\Lambda$. Consistent with the optimization in Appendix A, the functional forms are as follows:

$$
\begin{gathered}
D\left(C_{t}, C_{t-1}, \frac{D_{t}}{P_{c, t}}\right)=c_{1} \frac{C_{t}^{\varrho_{1}} C_{t-1}^{\varrho_{2}} \bar{C}^{1-\varrho_{1}-\varrho_{2}}}{D_{t} / P_{c, t}}\left(\log \left(\frac{C_{t}^{\varrho_{1}} C_{t-1}^{\varrho_{2}} \bar{C}^{1-\varrho_{1}-\varrho_{2}}}{D_{t} / P_{c, t}}\right)-c_{o}\right), \\
H\left(D_{t}, H_{t}\right)=\frac{1}{\beta}+h_{1} \frac{D_{t}}{H_{t}}\left(\log \left(\frac{D_{t}}{H_{t}}\right)-h_{o}\right), \\
\Lambda\left(\frac{D_{t}}{H_{t}}\right)=h_{1}\left(\log \left(\frac{D_{t}}{H_{t}}\right)-h_{o}\right), \\
F\left(\frac{N_{Y, t}}{M_{Y, t}}, \frac{N_{Y, t-1}}{M_{Y, t-1}}, \frac{N_{Y, t+1}}{M_{Y, t+1}}\right)=1+\frac{\psi_{y}}{\gamma_{N}}\left(\log \left(\frac{N_{Y, t}}{M_{Y, t}} / \frac{N_{Y, t-1}}{M_{Y, t-1}}\right)-\frac{\beta \psi_{y}}{\gamma_{N}}\left(\log \left(\frac{N_{Y, t+1}}{M_{Y, t+1}} / \frac{N_{Y, t}}{M_{Y, t}}\right) .\right.\right.
\end{gathered}
$$

Regarding calibration, Table 1 contains all parameter values and key steady state ratios, organized by economic agent. Choosing parameter values for Zambia was a difficult exercise, and our calibration is tentative. To our knowledge, there has been little empirical work-either micro-level studies or econometric estimates of macro models-that would

\footnotetext{
${ }^{16}$ See Appendix B for a description of the data.

${ }^{17}$ This choice is inconsequential: the correlation between the inverse of the money multiplier and the authorities' measure of excess liquidity, at the monthly frequency, was 0.92 during 2008-2010.
} 
help inform the calibration; more work is clearly needed in this area. Our approach was the following:

- All the relevant steady state ratios $\left(P_{C}^{-} C / \bar{D}, \bar{D} / \bar{H}, \bar{F} / \overline{Y^{N}}, \bar{T} / \overline{Y^{N}}, P_{C}^{-} G / \overline{Y^{N}}, \bar{B}^{\bar{b} k} / \overline{Y^{N}}\right)$ are calibrated to the Zambian economy. Parameters $\gamma_{M}, \omega$ and $\alpha$ are also chosen to replicate the degree of openness of the economy.

- Several parameters $\left(\chi, \xi_{w}, \varsigma, \gamma_{M}\right.$ and $\left.\xi_{c}\right)$ are set in accordance with recent empirical work on African countries (Berg, Portillo and Unsal (2010), Berg and others (2010)).

- Some parameters $\left(\beta, \delta, \sigma_{K}, \psi_{y}\right.$ and $\left.\xi_{R}\right)$, for which there is no Zambia- or LIC - specific data, are set to standard values in the literature.

- We set $g_{1}$ to zero to explicitly remove the financial accelerator from the analysis. This transmission channel was not helping match the dynamics of the crisis. Since we believe it may be relevant in other situations and for other countries, we leave it in the model for future use. ${ }^{18}$

- The value of $\psi_{X}$ reflects our prior that real exports in Zambia are likely to be fairly unresponsive to movements in the real exchange rate, mainly because copper exports represent 75 percent of total exports.

- We choose the money growth specification for monetary policy. In our baseline we assume monetary authorities do not respond to broad money or loan growth, which is consistent with the response during the crisis. We relax that assumption in our sensitivity analysis.

- On the government side, we choose $\phi, \tau_{G}$, and $\rho_{G}$ to broadly reproduce the path of fiscal variables during the crisis.

- The remaining parameters are chosen to improve the fit of the model. On the consumers' side this applies to $\varrho_{1}$ and $\varrho_{2}$ (parameters that affect the income elasticity of broad money demand). On the banks side, the parameters chosen this way are $\iota$ (related to the interest elasticity of reserve money demand), $\mu_{2}, \mu_{3}$ and $\mu_{4}$ (related to the shock to banks' appetite for risk). Note that $\varrho_{1}, \varrho_{2}$ and $\iota$ help shape the path of broad and narrow money during the crisis but do not alter the sign of the response. We discuss the choice of $\mu_{i}$ 's in subsection F.

As can be seen from our calibration of the last set of parameters, our approach differs somewhat from a pure calibration exercise. In particular, we use the information derived from fitting the model to the data to improve our choice of the last group of parameters, some

\footnotetext{
${ }^{18}$ In an earlier specification of our model we attempted to reproduce the crisis without the banking shock but with an active financial accelerator. This specification could generate the observed increase in lending rates but at the cost of a counterfactual increase in the current account deficit and an increase in private sector loans. The increase in loans was required for the premium to increase endogenously, as the model could not generate a sufficient decrease in the price of domestic capital (an alternative way of generating an increase in the premium). For this reason we decided to focus on an exogenous shock to the banking sector instead.
} 
of which do not have a specific micro-foundation to support them. This approach could be defined as informal/partial estimation. We believe our approach is justified by the the purpose of our model, which is to serve as a data-consistent story-telling device.

\section{Overview of shocks and the transmission mechanism}

Before analyzing Zambia's experience during the crisis, we briefly present impulse responses of key model variables to each of the four shocks in our model. This will help illustrate the underlying transmission channels. Figure 2 summarizes the model's response to a terms of trade improvement of 20 percent and to a loosening of monetary policy expressed as an increase in the growth rate of reserve money by 10 percent, respectively. Both shocks lead to a temporary increase in domestic demand and output, as is shown in the path of real imports, money demand and GDP growth. They differ in terms of their effect on inflation: the terms of trade improvement appreciates the exchange rate and lowers inflation, while the monetary loosening leads to higher inflation and nominal depreciation. The effects of the two shocks are also qualitatively different for the volume of credit to the private sector. While the policy loosening encourages higher borrowing and an increase in real credit, the terms of trade improvement results in a decrease in the volume of private credit, reflecting consumption smoothing.

Figure 3 summarizes the impulse response functions to the two risk shocks in the model: a 10 percentage-point increase in the shock to the country-wide risk premium $u_{R}$, and a shock to the banking sector's risk appetite $u_{F}$, such that-all else equal-the premium on the "notional" lending rate would increase by 5 percentage points. The increase in the country premium leads to a nominal depreciation, with upward pressure on inflation and an ensuing increase in policy and lending rates, which in turn leads to a contraction in domestic demand and output. The banking shock, on the other hand, leads to a squeeze in credit and a sharp fall in real imports. The fall in domestic demand triggers disinflation, lowers marginal costs for exporters and together with the drop in imports, improves the current account and contributes to higher GDP. ${ }^{19}$ Finally, the shock to banks' risk appetite would-by itself_-generate a nominal and real appreciation, as the demand for imports would fall.

Overall, the transmission channels operate as one would expect from a model of this type, although it must be emphasized that some of the shocks are pushing key variables (such as exchange rates and the current account) in opposite directions. The interesting question for the remainder of the paper is whether the model can provide us with explanations to our case study of Zambia, given the particular constellation of shocks and policy responses the country faced during the crisis.

\footnotetext{
${ }^{19}$ The expansion in GDP observed for the shock to $u_{F}$ is a common finding in models of sudden stops, which also involve shocks to a binding collateral constraint as in equation (1). See Chari, Kehoe and McGrattan (2005).
} 


\section{Replicating the crisis}

Having analyzed the impact of each shock separately, we now combine them together to mimic the impact of the crisis. As mentioned earlier, the aim here is to replicate Zambia's external environment during this period. Our approach is as follows. We set the path of the terms of trade shock $u_{T, t}$ and the risk premium shock $u_{R f, t}$ such that the model's terms of trade and nominal exchange rate exactly replicate their counterparts in the data from 2008:Q4 to 2010:Q2.

Regarding the shock to the banks' risk appetite $u_{F, t}$, we set their path so as to match the current account from 2008:Q4 to 2009:Q4. We focus on the mapping between the current account and banks' appetite for risk for the following reasons. Given the structure of the banking sector in the model (all of the country's financing including foreign borrowing goes through the banking sector), this shock has direct implications for the current account behavior. This linkage is consistent with the literature on sudden stops, where the external shock enters the model in the same way as our shock $\mu_{F, 1, t}$ in equation (1). ${ }^{20}$ In addition, the mapping between the banking shock and the current account reversal is also consistent with the fact that Zambia's banking system is largely foreign-owned, so that a change in banks's attitude toward domestic loans would likely be reflected in capital flight. ${ }^{21}$

Regarding monetary policy, we set the path of shocks $u_{M, t}$, such that the model replicates the observed path of the 90-day T-bill rate in Zambia during the same period. As will become evident later, we believe the behavior of monetary authorities cannot be characterized by a systematic rule but rather as a sequence of discretionary policy measures. The use of shocks to mimic the policy response is therefore more appropriate. Finally, to ensure consistency with the standard analysis of impulse responses in this type of models, we assume the path of shocks is fully anticipated at the beginning of our simulations (which corresponds to 2008Q3 in the data).

The mapping between shocks and selected variables warrants some discussion. We use the IRIS toolbox, developed by one of our coauthors, to implement this mapping. The procedure requires (i) solving the linear approximation of the model using standard rational-expectations techniques, under the assumption that all shocks are anticipated at the beginning of the simulation; (ii) inverting the VAR representation of the model's solution to recast the shocks as linear functions of the model variables (including leads and lags); and (iii) backing out the sequence of shocks that is necessary to reproduce the path of selected variables. The IRIS toolbox contains built-in functions to carry out this procedure.

\footnotetext{
${ }^{20}$ See Christiano, Gust and Roldos (2004) and Chari, Kehoe, and McGrattan (2005), among others.

${ }^{21}$ It is possible however that the contraction in credit might have been due to domestic considerations unrelated to- but coincident with — capital outflows. In this case there would be two different shocks, one accounting for the capital outflows and the other for the contraction in credit.
} 


\section{E. Baseline results}

Conditional on the four "hard-tuned" variables above, we simulate the model's response and compare the remaining model variables with their counterparts in the data. The starting point of the data and the model is the same in most cases, except for inflation and the growth rate of reserve money, for which the model's starting point is the pre-crisis average. By doing so, we are assuming that the economy was broadly at trend before the crisis hit. We return to the pre-crisis behavior of inflation in the last section.

First, we characterize the evolution of the key observed variables during the crisis, starting in 2008-IV (Figure 2). Along with the terms of trade deterioration we observe an immediate depreciation of the nominal exchange rate $S$. The exchange rate depreciation feeds initially into higher inflation. The current account reversal is in the order of 20 percentage points of quarterly GDP, reflecting the exit of foreign investors. ${ }^{22}$ The capital flight is associated with a large contraction in the volume of credit issued by the domestic banking system and an increase in lending rates, which prevents private agents from borrowing abroad to smooth out the effects of the crisis. Aggregate demand contracts significantly as a result of the credit crunch and inflation subsequently declines, while real deposits in the banking sector decrease by over 15 percent. ${ }^{23}$ Note that the behavior of GDP, which has been interpolated to generate quarterly series, is not consistent with the overall macroeconomic picture. The fiscal outcome worsens - especially revenues - and the outstanding stock of government debt increases by about 20 percent.

In this context the initial monetary policy response can be characterized as contractionary. Interest rates on treasury bills increase by about 400 basis points between July 2008 and July 2009. This is associated with a decrease in the growth rate of the monetary base and contributes to the contraction of broad money and the increase in lending rates.

Starting in July 2009 however, there is a reversal in the monetary stance in response to the slowdown. Liquidity is injected into the banking system ( $H$ increases) above the pre-crisis level and the T-bill rate drops sharply, by about 1300 basis points by July 2010. This loosening policy drives down the lending rate and brings aggregate demand slowly back towards the baseline level. The monetary loosening coincides with an recovery of the terms of trade which appreciates the exchange rate, lowers inflation, and supports the recovery in demand.

How does the model predictions compare with the data? In general, the model performs well qualitatively and comes close to the data for the lending rate, inflation rate and import demand. For the other variables, the model predicts correctly the direction although the magnitudes are, as can be expected, not always closely matched. For example, in the model, credit to the private sector contracts faster and stronger than in the data, as is also the case

\footnotetext{
${ }^{22}$ A preliminary revision of the current account balance—by the country's authorities—now indicates a large surplus for 2009, which provides further confirmation of the sudden stop experienced during the crisis.

${ }^{23}$ Part of the decline in inflation could be accounted for by the fall in the international prices of food and fuel in the second half of 2008. We do not account for such effects here.
} 
with real money demand, while credit to the government is predicted to surge faster than in the data. The fiscal variables (revenues and spending as share of GDP) are slightly more volatile in the data than the model predicts. Clearly, the model cannot account for all sources of rigidities or policies that may shape the path of the economy. There are more sources of government and private credit funding, such as aid donors, non-banks etc. which may generate either additional volatility or delays in some of the macro responses that the model does not capture.

Regarding GDP growth however, the model's prediction are completely at odds with the data: the model predicts a large contraction in GDP while the data indicates no such contraction. One interpretation is that in reality, unlike the model, the decline in external financing is not contractionary, perhaps because output is not demand determined. However, part of the divergence may be explained by positive shocks to the supply side of the economy. ${ }^{24}$ Mismeasurement of economic activity may also account for some of the gap.

\section{A digression on fiscal policy}

Beyond its quantitative properties, the model also illustrates how fiscal policy affects the transmission of external shocks. As mentioned earlier, the fiscal outlook worsened as a result of the global crisis, and public debt increased. In normal circumstances, holding everything else constant, such an increase in debt would have been financed in part by capital inflows and in part by a crowding out of private sector credit and an increase in interest rates. In this case however the increase in debt coincides with a large decrease in private sector credit and a reversal of capital flows. While these two factors are pushing in opposite directions, the net effect more than outweighs the effects of fiscal policy. Holding reserve money growth constant the T-bill rate would have decreased. However, for a given current account path, higher government debt would have resulted in an additional decline in private sector credit. Note that the impact on aggregate demand from stable government spending (financed by debt) is positive.

\section{F. Shock decomposition}

It is helpful to analyze how the different shocks contributed to each variable's dynamics. ${ }^{25}$ Figure 5 presents the path of all three external shocks. The initial path of all three shocks is consistent with the above narrative: there is an increase in banks' risk aversion (positive $u_{F}$ ) through the first five quarters, a deterioration in the terms of trade (negative $u_{T}$ ) that recovers by the end of 2009, and an increase in the country-risk premium from 2009 to 2010 Q 2 (positive $\left.u_{R}\right)^{26}$

\footnotetext{
${ }^{24}$ IMF (2010a) mentions a bumper harvest and the coming on stream of a new copper mine.

${ }^{25}$ The IRIS toolbox is ideally suited for this type of exercise.

${ }^{26}$ The initial drop in $u_{R}$ results from the forward-looking behavior of the exchange rate and is necessary to maintain consistency of the observed exchange rate with the UIP condition.
} 
Figure 6 presents the shock decomposition for three nominal variables: the nominal exchange rate, the lending rate and the inflation rate. One striking observation is that the shocks are generating opposing effects on the dynamics of these variables. The terms of trade and external risk premium shocks $\left(u_{T}, u_{R}\right)$ are generating pressures for nominal exchange rates to depreciate and lending rates and inflation to increase, while the banking sector shock $\left(u_{F}\right)$ is having the opposite effect.

More importantly, the banking shock plays an important role in the transmission of the crisis. This reflects the dominant role of the banking sector in our model. The decrease in banks' risk appetite through the end of 2009 exerts a downward pressure on inflation and the exchange rate, as it generates a decline in consumption, including for imports. The overall effect of the banking shock on lending rates is negative, despite the appearance of the shock in equation (16): as the shock makes private demand contract and inflation fall, the endogenous response of monetary policy-combined with a contraction in the demand for money-makes T-bill (and lending) rates fall.

Figure 7 shows the shock decomposition for the volume of credit to the private sector, credit to the public sector and real imports. The figure reveals how strongly the credit rationing of banks affected the contraction in lending and import demand. In the absence of the banking shock, the other two shocks would have resulted in an increase in lending for smoothing purposes. In the case of government debt, all shocks are initially contributing to its increase.

Finally, note that the tightening of monetary policy exacerbates the negative impact of the shocks in the initial quarters. The lending rate is further increased, private credit is further reduced and demand (see imports) contracts slightly more given this tightening policy. However, relative to the contribution of the external and financial shocks triggered by the crisis, the impact of policy is far less decisive for the evolution of demand and economic activity. This reflects the severity and sheer magnitude of the exogenous shocks that hit the economy during this episode. In the following section, the role of monetary policy is discussed in detail.

Having described the performance of the model and how each shock contributed to the path of key variables, we can now justify our choice for the weights on the different components of the bank risk shock (the $\mu_{i} \mathrm{~s}$ ). As can be seen from the shock decomposition exercise, the greatest impact of the bank risk shock is on credit volumes. This makes it natural to normalize the shock to consumers' borrowing constraint $\left(u_{F, 1, t}\right)$ and guided our calibration of the overall bank shock itself $\left(u_{F, t}\right)$. The choice of $\mu_{F, 2}$ is guided by the observation that $\left(u_{F, 1, t}\right)$ is highly contractionary, as it has large effects on aggregate demand. Shocks to import financing $\left(u_{F, 2, t}\right)$ do not have such large effects; a substantial weight on $\left(u_{F, 2, t}\right)$ is thus helpful in matching the large current account reversal absent a notable output decline. The increase in lending spreads helps calibrate $u_{F, 3, t}$-absent such a shock, lending spreads would not increase. Finally, $u_{F, 4, t}$ helps track the behavior of reserve money. In its absence the model would require an implausibly large contraction in reserve money to replicate the path of the T-bill rate. 


\section{G. The role of the monetary policy response: shock counterfactuals}

Recall that the monetary policy rule is specified in terms of the growth rate of reserve money, reproduced here for convenience:

$$
\frac{H_{t}}{H_{t-1}}=1-\kappa_{\pi, H}\left(\pi_{c, t+1}-1\right)-\kappa_{D, H}\left(\frac{D_{t}}{D_{t-1}}-1\right)-\kappa_{L, H}\left(\frac{L_{t}}{L_{t-1}}-1\right)-u_{M, t}
$$

with discretionary deviations from the rule captured by the shock process $u_{M, t}$.

Figure 8 displays the decomposition of the dynamics of reserve money growth, the T-bill rate and real broad money. Not surprisingly, the monetary shock accounts for most of the movements in reserve money growth and the t-bill rate. In other words, fluctuations in monetary policy are directly responsible for the behavior of two key nominal variables (short rates and reserve money growth). This is not true of real money variables: most of the variance of real broad money balances is accounted for by the real shocks.

To assess the role of policy, we first simulate the model without policy shocks. Figure 9 compares the model dynamics with and without policy shocks. In contrast with the previous stop and go pattern, reserve money growth is now mostly flat. Given the contraction in demand for broad money, this results in an initial decline in the T-bill rate, which amplifies the nominal depreciation and raises inflation. At the same time, the increase in the lending rate is not as large, as liquidity is more abundant than under baseline. Another clear effect of the neutral monetary policy is the dampening of the increase in outstanding public debt since the lower T-bill rate implies lower debt servicing costs.

In terms of real variables, the effect of the accommodating policy stance appears to be limited. The contraction on import demand is slightly smaller, as is the contraction in credit to the private sector. A closer look reveals sizeable effects however. Table 2 summarizes the relative performance of alternative policy responses, relative to the baseline, along a number of dimensions. The average difference between private spending $\left(C_{t}\right)$ under "stop and go" and under the more neutral stance, over the period 2009:I to 2009:IV, is 2.8 percent of steady state spending. During the same period the model predicts a moderately higher inflation-3 percentage points higher-although in line with Zambia's implied inflation target of 10 percent, while the nominal exchange rate would have been 12 percent more depreciated.

Figure 10 displays simulation results if monetary policy had actually been loosened, i.e., money growth higher than average during 2009:I to 2009:IV. The inflationary effects are now larger (see also Table 2). Inflation is now 6 percentage points higher than under the baseline, while the nominal exchange rate is 24 percent more depreciated. However, the model predicts lending rates would have stayed flat and private spending would have been 5.4 percent higher. One important observation is that, given the steady state value of the T-bill nominal interest rate, there is a lot of room for interest rates to fall-thirteen hundred basis points-without hitting the zero lower bound. In this scenario monetary policy comes very close to hitting the zero bound but stays above it. 


\section{H. The role of the monetary policy response: rule counterfactuals}

We now explore the performance of the model under three alternative policy rules. In the first case, the authorities still implement an inflation-targeting regime by setting targets for reserve money growth, but they also respond to deviations in broad money growth from its long run value $\left(\kappa_{D, H}=0.5\right)$. In the second case, we assume the authorities target the growth rate of loans rather than the growth rate of deposits $\left(\kappa_{L, H}=0.3\right)$. In the third case, we assume the authorities follow the interest rate rule:

$$
R_{B, t}=\rho_{R} R_{B, t-1}+\left(1-\rho_{R}\right)\left(\bar{R}_{B}+\kappa_{\pi}\left(\pi_{c, t+1}-1\right)\right)+u_{M, t},
$$

with $\rho_{R}=0.5$ and $\kappa_{\pi}=3$.

The results are summarized in Table 2. All three rules would have improved the country's private spending performance, although again at the cost of higher inflation and nominal depreciation. The conclusion from this exercise is that policy makers were confronted to a tradeoff: while a loser policy would have helped weather the external shocks, the country would have faced somewhat higher inflation as a result. This reflects the nature of the "global crisis" shock, which does not easily lend itself to an aggressive monetary policy response. In this case there is no "divine coincidence" (Blanchard and Gali (2010)).

\section{UNDERSTANDING THE INITIAL MONETARY POLICY RESPONSE}

In this section we analyze the motivation behind the initial policy response. We start by looking at the behavior of policy before mid-2008 (see Figure 11). Interest rates were broadly constant prior to the crisis but then began to increase steadily around or possibly a few months before the onset of the crisis. What factors can account for such behavior?

We can divide the factors depending on when they occurred. Following the metaphor from the introduction, we distinguish between 'rear-view' factors and 'side-view' factors. The former refer to factors that, while having occurred in the past, were still influencing policy; the former refer to factors that were occurring at the time of the policy decision.

The first 'rear view' factor is inflation itself. When simulating the model and confronting it to the data, we made the simplifying assumption that the economy was starting from steady state. As we mentioned earlier, this assumption was more-or-less valid for most variables in our sample, with the notable exception of inflation. Figure 11, top right corner, shows the monthly behavior of year-on-year inflation since 2006. As is clearly visible, inflation had begun increasing steadily since end 2007, going from 8.9 to 16.6 percent by December 2008 . The increase is mostly accounted for by food prices which had gone from close to 0 to 21 percent between end 2006 and end 2008. Note that non-food inflation was falling throughout most of 2008 . 
It was well understood at the time that food inflation was driven by the ongoing global food and fuel shocks of 2007-2008, during which the price of most commodities doubled or tripled in a few months. While the policy adage is to allow for first round (direct) effects of such shocks and to prevent second round (indirect) effects, there was a concern at the time that inflation risked loosing its anchor and that a policy tightening was needed. ${ }^{27}$

An additional and related 'rear view' factor was the consistent miss of reserve money targets during 2009. Table 3 displays the targets and the actual levels of reserve money. ${ }^{28}$ The misses reflected an intentional accommodation of the surge in demand for nominal balances as a result of higher inflation, and were interpreted at the time as indicating neutral policy. However, the gradual increase of T-bill rates during 2008 suggests policy was not as accommodative as the target misses suggested.

The combination of target misses and high inflation in 2008 led to an effort to (further) tighten policy in 2009. This can be seen by looking at the targets set-at the end of 2008-for reserve money growth in mid 2009 (see Table 3), which were lower than end-2008 values. The targets were subsequently revised midway through 2009 , coinciding with the large fall of T-bill rates. It is worth noting that the targets were missed in the opposite direction in the second half of 2009, suggesting the authorities did not anticipate the crisis-induced decline in demand for reserve money during that period.

In terms of 'side-view' factors, we believe the nominal depreciation-and the associated capital flight — may have made the authorities reluctant to loosen policy sooner. Indeed, during the second half of 2008, the nominal exchange rate had depreciated by 50 percent, and foreign direct and portfolio investments had fallen by more than 30 percent. As predicted by our model, a loosening would have accelerated capital flight and amplified the nominal depreciation, the prospects of which were likely to concern the authorities.

Finally, an additional 'side-view' consideration may have been the reluctance to provide the banking sector with additional liquidity as the banking system appeared to have ample liquidity. As Figure 11 indicates, the ratio of reserve money to broad money had been increasing since the end of 2007 , by about 20 percent by end 2008 , which may have reinforced the perception that monetary policy was loose. In our model, such dynamics were driven instead by the fall in broad money and the increase in liquidity demand by banks, which indicates policy was actually tight instead.

\section{Conclusion}

We have shown that a DSGE model, fitted to the specifics of low-income country, provides a good characterization of Zambia's performance during the crisis. We believe our framework,

\footnotetext{
${ }^{27}$ see IMF (2009).

${ }^{28}$ These targets were set in the context of the Fund-supported Policy Reduction and Growth Facility arrangement. Targets for 2008 were set early 2008, targets for 2009 were set early 2009, with a revision mid 2009. See IMF (2009).
} 
which implements the model in IRIS, is well suited for confronting the model with data and for making forecasts conditional on various policy scenarios.

Our analysis yields several lessons for policy makers in low-income countries. First, monetary policy should be forward-looking and respond to current or expected shocks, instead of responding to the current inflationary effects of past shocks. Such a strategy of "driving by looking through the rear-view mirror" exposes the central bank to potentially large policy mistakes that need to be reversed later, further contributing to economic instability. Second, central banks should avoid paying excessive attention to banks' liquidity - or reserve money—as the exclusive indicator of the monetary policy stance-a common practice in sub-Saharan Africa. Rather than loose monetary policy, the buildup of liquidity may reflect growing risk aversion in the banking system. More generally, central banks in the region need to monitor overall developments in the banking system, including credit volumes and interest rate premia, in order to gauge the right policy stance. These lessons are well understood in developed and emerging market countries but they have yet to take hold in low-income countries.

While reserve money targeting remains a common practice in sub-Saharan Africa, the flexibility with which it is implemented can help avoid potential policy mistakes. In addition, as central banks in the region move toward incorporating additional elements of inflation targeting in their frameworks - with its emphasis on the inflation forecast, greater policy clarity, less reliance on monetary aggregates, and a greater role for short-term rates- the response to large unexpected events should improve.

Our model has also shown however, that—at present-monetary policy in LICs may be limited in its ability to offset large external shocks. These shocks-worsening in the terms of trades, increases in risk premia - confront policy makers with unpleasant tradeoffs between output and inflation. Our results also show, however, that monetary policy errors can add to the volatility. More generally, a systematic forward-looking policy response can enhance credibility and anchor expectations in a way that should reduce over time these unpleasant tradeoffs.

From an analytical perspective, we have found it important to model the crisis as a combination of shocks. In particular, we have found that the inclusion of the shock to the banking sector-itself a collection of shocks to various aspects of the banks' profit maximization conditions-greatly improves the quantitative performance of the model. Further analysis of the mechanisms underlying these shocks is a fruitful topic for further research.

Our framework has abstracted from other key aspects of central bank policy in low-income countries, most notably the direct intervention in foreign exchange markets. In a related paper, some of the coauthors analyze the interaction of monetary policy rules with rules describing foreign exchange rate interventions. ${ }^{29}$ We have also abstained from analyzing in greater detail the challenges posed by fiscal policy in the implementation of monetary policy,

${ }^{29}$ see Benes, and others (2010). 
even though our model explicitly incorporates the fiscal sector. Some of us have explored the interaction of fiscal and monetary policy in the context of aid shocks, but more work is needed in this area. ${ }^{30}$

\section{APPENDICES}

\section{A. Appendix A}

\section{Notational conventions}

- Bars denote variables externalised from an agent's decision, e.g. external habit $\bar{C}_{t}$, etc.

- Lower-case letters denote various types of adjustment costs and parameters that quantify these costs, e.g. $w_{t}, w_{1}$, etc.

- Time $t$ choice variables have always a time $t$ index.

\section{Households}

Each household consumes a bundle of directly imported and locally produced goods, supplies labour in a monopolistically competitive labour market, holds two types of assets (bank deposits and physical capital) and has access to bank loans. The household chooses $C_{t}$, $N_{t}, W_{t}, L_{t}, D_{t}, K_{t}$ to maximise its lifetime utility,

$$
E_{t} \sum_{t=0}^{\infty} \beta^{t}\left[\log \left(C_{t}-\chi \bar{C}_{t-1}\right)-N_{t}\right]
$$

subject to a budget constraint

$$
\begin{aligned}
D_{t}+P_{K t} K_{t}-L_{t}=R_{D t-1} D_{t-1}-R_{L t-1} L_{t-1}+ & P_{K t} K_{t-1}(1-\delta) \\
& +Q_{t} K_{t-1}+W_{t} N_{t}\left(1-w_{t}\right)-P_{t} C_{t}\left(1+c_{t}\right)+T_{t},
\end{aligned}
$$

a borrowing constraint:

$$
L_{t} \leq \bar{L}_{t}
$$

and a labor demand curve

$$
N_{t}=\left(W_{t} / \bar{W}_{t}\right)^{-\frac{\mu}{\mu-1}} \bar{N}_{t}
$$

where $T_{t}$ is a net government transfer (or a net tax with a minus sign), $\mu$ is the degree of the household's monopoly power in the labor market, $w_{t}$ is a wage adjustment cost,

$$
w_{t}:=\frac{w_{1}}{2}\left[\log \left(W_{t} / W_{t-1}\right)-\log \left(\bar{W}_{t-1} / \bar{W}_{t-2}\right)\right]^{2},
$$

\footnotetext{
${ }^{30}$ see Berg, Mirzoev, Portillo and Zanna (2010).
} 
and $c_{t}$ is a transaction cost increasing in the ratio of consumption purchases to deposit holdings:

$$
c_{t}=\frac{c_{1}}{2}\left[\log \left(P_{t} C_{t} / D_{t}\right)-c_{0}\right]^{2} .
$$

The household's consumption, $C_{t}$, is a Leontieff bundle of domestically produced goods:

$$
C_{t}=\min \left(\frac{C_{D, t}}{\omega}, \frac{C_{M, t}}{1-\omega}\right),
$$

where $\omega$ is the share of domestic goods.

\section{Wholesale production}

The representative producer of local goods uses three types of inputs, labour, $N_{t}$, imported intermediates, $M_{Y t}$, and capital, $K_{t}$, to produce her output in a competitive market using the following production function

$$
Y_{t}=N_{t}^{\gamma_{N}} M_{Y, t}^{\gamma_{M}} K_{t}^{1-\gamma_{N}-\gamma_{M}}
$$

She sells the goods to local retailers and to exporters in a competitive market taking the prices as given. She chooses $Y_{t}, N_{t}, Y_{M t}$ and $\mathcal{K}_{t}$ to maximise

$$
\varepsilon_{0} \sum_{t=0}^{\infty} \beta^{t} \Lambda_{t}\left[P_{Y t} Y_{t}\left(1-y_{t}\right)-W_{t} N_{t}-P_{M t} Y_{M t}-Q_{t} \mathcal{K}_{t}\right]
$$

subject to the above production function, and a cost of adjusting the input proportion of labour and intermediates,

$$
y_{t}=\frac{\psi_{1}}{2}\left[\log \left(N_{t} / Y_{M t}\right)-\log \left(N_{t-1} / Y_{M t-1}\right)\right]^{2} .
$$

\section{Local retail}

Local retailers re-sell the domestically produced goods in a local, monopolistically competitive market to households. Each retailer chooses its output, $V_{t}$, and final price, $P_{t}$, to maximize

$$
\mathcal{E}_{0} \sum_{t=0}^{\infty} \beta^{t} \Lambda_{t}\left[P_{t} V_{t}\left(1-p_{t}\right)-P_{D t} V_{t}\right]
$$

subject to a demand curve

$$
V_{t}=\left(P_{D t} / \bar{P}_{D t}\right)^{-\frac{\mu}{\mu-1}} \bar{V}_{t}
$$


where $\mu$ is the retailer's degree of monopoly power in the local goods market, and $p_{t}$ is a price adjustment cost,

$$
p_{t}:=\frac{p_{1}}{2}\left[\log \left(P_{D t} / P_{D t-1}\right)-\log \left(\bar{P}_{D t-1} / \bar{P}_{D t-2}\right)\right]^{2} .
$$

\section{Export}

The representative exporter combines locally produced goods with re-exports (imported goods) in fixed proportion as perfect complements,

$$
\begin{gathered}
\alpha X_{t}=X_{Y t}, \\
(1-\alpha) X_{t}=X_{M t} .
\end{gathered}
$$

She chooses $X_{t}, X_{Y t}, X_{M t}$ to maximise

$$
E_{0} \sum_{t=0}^{\infty} \beta^{t} \Lambda_{t}\left[P_{X t} X_{t}\left(1-x_{t}\right)-P_{Y t} X_{Y t}-P_{M t} X_{M t}\right]
$$

taking the export prices, $P_{X t}$ as given (determined by in world goods market), where $x_{t}$ is an output adjustment cost,

$$
x_{t}:=\frac{\psi_{x}}{2}\left(\log X_{t}-\log X_{t-1}\right)^{2} .
$$

\section{Wholesale branches of commercial banks}

Commercial banks consist each of a wholesale branch and a retail branch. The wholesale branch makes decisions related to the structure of the bank's assets and liabilities while the retail branch extends credit to households.

The balance sheet of the wholesale branch of a representative bank consists of three types of assets: wholesale loans to the retail branch, $L_{t}$, liquidity held with the central bank, $H_{t}$, holdings of government bonds, $B_{t}$; and two types of liabilities: cross-border borrowing denominated in foreign currency, $F_{t}$, and local deposits, $D_{t}$ to maximise

$$
L_{t}+H_{t}+B_{b k, t}=F_{t}+D_{t}
$$

The branch chooses $L_{t}, H_{t}, B_{t}, F_{t}, D_{t}$ to maximise

$$
\mathcal{E}_{0} \sum_{t=0}^{\infty} \beta^{t+1} \Lambda_{t+1}\left[R_{L, t}^{*} \mathcal{L}_{t}+H_{t}\left(1-h_{t}\right)+R_{B t} B_{B t}-R_{F t}^{*} F_{t} \frac{S_{t+1}}{S_{t}}-R_{D t} D_{t}\right] .
$$


where $h_{t}$ is a cost of holding low liquidity (increasing the bank's deposit-to-liquidity ratio),

$$
h_{t}:=\frac{h_{1}}{2}\left[\log \left(D_{t} / H_{t}\right)-h_{0}\right]^{2} .
$$

\section{Retail branches of commercial banks}

The retail branch extends credit to households with some degree of monopoly power in the retail lending market. Retail lending is risky and the reatil lending rates are subject to adjustment costs. The retail branch chooses the volume of retail lending, $L_{t}$, and the retail rate, $R_{L t}$ to maximise

$$
\mathcal{E}_{0} \sum_{t=0}^{\infty} \beta^{t+1} \Lambda_{t+1}\left[R_{L t} L_{t}\left(1-g_{t+1}\right)\left(1-r_{t}\right)-R_{L, t}^{*} L_{t}\right],
$$

subject to a demand curve

$$
L_{t}=\left(R_{L t} / \bar{R}_{L t}\right)^{-\frac{v}{v-1}} \bar{L}_{t}
$$

where $g_{t}$ is the loss on loans (reflecting the fact that lending is risky, and hence that the banks are not always able to recover $100 \%$ of the repayments due), which itself is a function of the household loan-to-value ratio, $\frac{R_{L t} L_{t}}{P_{K t} K_{t}}$ (explained in the text), and $r_{t}$ is the retail rate adjustment cost,

$$
r_{t}=\frac{r_{1}}{2}\left[\log R_{L t}-\log R_{L t-1}\right]^{2} .
$$




\section{B. Appendix B}

\begin{tabular}{|c|c|c|c|c|}
\hline Description & Source & $\begin{array}{l}\text { Seasonally } \\
\text { adjusted }\end{array}$ & Frequency & Comments \\
\hline Broad Money/Deposits (M3) & $\begin{array}{l}\text { IFS/ } \\
\text { Bank of } \\
\text { Zambia }\end{array}$ & $\mathrm{x}$ & Monthly & $\begin{array}{l}\text { Aggregated to quarterly frequency } \\
\text { (averaging) }\end{array}$ \\
\hline Reserve money (M1) & $\begin{array}{l}\text { IFS/ Bank of } \\
\text { Zambia }\end{array}$ & $\mathrm{x}$ & Monthly & $\begin{array}{l}\text { Aggregated to quarterly frequency } \\
\text { (averaging) }\end{array}$ \\
\hline Commercial lending rates & $\begin{array}{l}\text { Bank of } \\
\text { Zambia }\end{array}$ & & Monthly & $\begin{array}{l}\text { Aggregated to quarterly frequency } \\
\text { (averaging) }\end{array}$ \\
\hline Headline CPI & $\begin{array}{l}\text { IFS/ } \\
\text { Bank of } \\
\text { Zambia }\end{array}$ & $\mathrm{x}$ & Monthly & $\begin{array}{l}\text { Aggregated to quarterly frequency } \\
\text { (averaging) }\end{array}$ \\
\hline CPI - Non-food & $\begin{array}{l}\text { IFS/Bank of } \\
\text { Zambia }\end{array}$ & $\mathrm{x}$ & Monthly & $\begin{array}{l}\text { Aggregated to quarterly frequency } \\
\text { (averaging) }\end{array}$ \\
\hline CPI - Food & $\begin{array}{l}\text { IFS/Bank of } \\
\text { Zambia }\end{array}$ & $\mathrm{x}$ & Monthly & $\begin{array}{l}\text { Aggregated to quarterly frequency } \\
\text { (averaging) }\end{array}$ \\
\hline $\begin{array}{l}\text { Exchange rate Kwacha per } \\
\text { USD }\end{array}$ & IFS & $\mathrm{x}$ & Monthly & $\begin{array}{l}\text { Aggregated to quarterly frequency } \\
\text { (averaging) }\end{array}$ \\
\hline US import price index & IFS & $\mathrm{x}$ & Monthly & $\begin{array}{l}\text { Aggregated to quarterly frequency } \\
\text { (averaging) }\end{array}$ \\
\hline $\begin{array}{l}\text { Net claims on private sector by } \\
\text { banks }\end{array}$ & $\begin{array}{l}\text { IFS/Bank of } \\
\text { Zambia }\end{array}$ & $\mathrm{x}$ & Monthly & $\begin{array}{l}\text { Aggregated to quarterly frequency } \\
\text { (averaging) }\end{array}$ \\
\hline $\begin{array}{l}\text { Stock of outstanding domestic } \\
\text { debt }\end{array}$ & $\begin{array}{l}\text { Bank of } \\
\text { Zambia }\end{array}$ & $\mathrm{x}$ & Monthly & $\begin{array}{l}\text { Aggregated to quarterly frequency } \\
\text { (averaging) }\end{array}$ \\
\hline Revenues and grants & $\begin{array}{l}\text { IMF } \\
\text { staff/Zambian } \\
\text { Authorities } \\
\text { (MOF) }\end{array}$ & $\mathrm{x}$ & Monthly & $\begin{array}{l}\text { Aggregated to quarterly frequency } \\
\text { (averaging) }\end{array}$ \\
\hline Total exports & $\begin{array}{l}\text { IMF staff/ } \\
\text { Zambian } \\
\text { Authorities } \\
\text { (MOF) }\end{array}$ & $\mathrm{x}$ & Monthly & $\begin{array}{l}\text { Aggregated to quarterly frequency } \\
\text { (averaging) }\end{array}$ \\
\hline 90-day Treasury bill rate & IFS & & Monthly & $\begin{array}{l}\text { Aggregated to quarterly frequency } \\
\text { (averaging) }\end{array}$ \\
\hline Deposit rate & $\begin{array}{l}\text { IMF } \\
\text { Staff/Bank of } \\
\text { Zambia }\end{array}$ & & Monthly & $\begin{array}{l}\text { Aggregated to quarterly frequency } \\
\text { (averaging) }\end{array}$ \\
\hline $\begin{array}{l}\text { Price of copper (USD per } \\
\text { metric tonne) }\end{array}$ & $\begin{array}{l}\text { London Metal } \\
\text { Exchange } \\
\text { (LME) }\end{array}$ & $\mathrm{x}$ & Monthly & $\begin{array}{l}\text { Aggregated to quarterly frequency } \\
\text { (averaging) }\end{array}$ \\
\hline $\begin{array}{l}\text { Nominal imports - Goods and } \\
\text { services (milions,USD) }\end{array}$ & $\begin{array}{l}\text { Bank of } \\
\text { Zambia }\end{array}$ & & Quarterly & \\
\hline $\begin{array}{l}\text { Current account (milions, } \\
\text { USD) }\end{array}$ & $\begin{array}{l}\text { Bank of } \\
\text { Zambia }\end{array}$ & & Quarterly & \\
\hline GDP at constant prices & IFS & & Yearly & $\begin{array}{l}\text { Interpolated to quarterlyfrequency } \\
\text { (quadratic interpolation) }\end{array}$ \\
\hline GDP at current prices & IFS & & Yearly & $\begin{array}{l}\text { Interpolated to quarterly frequency } \\
\text { (quadratic interpolation) }\end{array}$ \\
\hline GDP at current prices (USD) & IFS & & Yearly & $\begin{array}{l}\text { Interpolated to quarterly frequency } \\
\text { (quadratic interpolation) }\end{array}$ \\
\hline
\end{tabular}




\section{REFERENCES}

Adam, Christopher, and Stephen O'Connell, 2006,"Monetary Policy and Aid Management in Sub Saharan Africa," Unpublished manuscript.

Adrian, Tobias, and Hyung Song Shin, 2011, 'Financial Intermediation and Monetary Economics," in Benjamin Friedman and Michael Woodford, eds., Handbook of Monetary Economics. Amsterdam: North Holland.

Agenor, Pierre-Richard, and Peter Montiel, 2006, "Credit Market Imperfections and the Monetary Transmission Mechanism. Part I: Fixed Exchange Rates," The School of Economics Discussion Paper Series 0628. (Manchester: The University of Manchester).

Agenor, Pierre-Richard, and Peter Montiel, 2008, "Monetary Policy Analysis in a Small Open Credit-Based Economy," Open Economies Review, Vol. 19, No. 4, pp. 423-455.

Aghion, Philippe, Philippe Bacchetta, and Abhijit Banerjee, 2001, "Currency Crises and Monetary Policy in an Economy with Credit Constraints," European Economic Review, Vol. 45, pp. 1121-1150.

Baldini, Alfredo, and Marcos Poplawski-Ribeiro, 2011, "Fiscal and Monetary Determinants of Inflation in Low-Income Countries: Theory and Evidence from Sub-Saharan Africa", Journal of African Economies (forthcoming).

Benes, Jaromir, Andrew Berg, Rafael Portillo, and David Vavra, 2011, "Modeling Sterilized Interventions and Balance Sheet Effects of Monetary Policy," Unpublished manuscript.

Berg, Andrew, Philip D. Karam, and Douglas Laxton, 2006, “A Practical Model-Based Approach to Monetary Policy Analysis-Overview,’IMF Working Paper 06/80.

Berg, A., T. Mirzoev, R. Portillo, and L.F. Zanna (2010), “The Short-Run Macroeconomics of Aid Inflows: Understanding the Interaction of Fiscal and Reserve Policy," IMF Working Paper 10/65.

Berg, Andrew, Rafael Portillo, and Filiz Unsal, 2010, "Optimal Adherence to Money Targets in Low-Income Countries," IMF Working Paper 10/134.

Berg, Andrew, Chris Papageorgiou, Catherine Pattillo, and Nikola Spatafora, 2010, "The End of an Era? The Medium- and Long-Term Effects of the Global Crisis on Growth in Low-Income Countries," IMF Working Paper 10/205.

Bernanke, Ben and Alan Blinder, 1988, "Credit, Money and Aggregate Demand" American Economic Review, Vol. 78, No. 2, pp. 435-439.

Bernanke, Ben, Mark Gertler, and Simon Gilchrist, 1999, "The Financial Accelerator in a Quantitative Business Cycle Framework," in John Taylor and Michael Woodford, eds., Handbook of Macroeconomics. Amsterdam: North Holland. 
Bester, Helmut, and Martin Hellwig, 1987, "Moral Hazard and Equilibrium Credit Rationing: An Overview of the Issues," in Gunter Bamberg and Klaus Spremann, eds., Agency Theory, Information and Incentives. Berlin: Springer-Verlag.

Calvo, Guillermo, 1998, "Capital Flows and Capital-Market Crises: The Simple Economics of Sudden Stops," Journal of Applied Economics, Vol. 1, No. 1, pp. 35-54.

Calvo, Guillermo, Alejandro Izquierdo, and Ernesto Talvi, 2006, "Sudden Stops and Phoneix Miracles in Emerging Markets," American Economic Review Papers and Proceedings, Vol. 96, No. 2, pp. 405-410.

Chari, V. V., Patrick J. Kehoe, and Ellen R. McGrattan, 2005, ”Sudden Stops and Output Drops," American Economic Review Papers and Proceedings, Vol. 95, No. 2, pp. 381-387.

Christiano, Lawrence, Christopher Gust, and Jorge Roldos, 2004, "Monetary Policy in a Financial Crisis,” Journal of Economic Theory, Vol. 119, pp. 64-103.

Christiano, Lawrence, Roberto Motto, and Massimo Rostagno, 2010, "Financial Factors in Economic Fluctuations,” European Central Bank Working Paper 1192.

Curdia, Vasco, and Michael Woodford, 2009,“Credit Frictions and Optimal Monetary Policy,” Unpublished manuscript, Columbia University.

Erceg, Christopher, Luca Guerrieri, and Christopher Gust, 2006, "SIGMA: A New Open Economy Model for Policy Analysis," International Journal of Central Banking, Vol. 2, No. 1, pp. 1-49.

Gertler, Mark, and Nobuhiro Kiyotaki, 2011, "Financial Intermediation and Credit Policy in Business Cycle Analysis," in Benjamin Friedman and Michael Woodford, eds., Handbook of Monetary Economics. Amsterdam: North Holland.

Ghosh, Atish, Charis Christofides, Jun Kim, Laura Papi, Uma Ramakrishnan, Alun Thomas and Juan Zaldendo, 2005, "The Design of IMF-Supported Programs," IMF Occasional Paper 241. (Washington:International Monetary Fund).

Goodfriend, Marvin, and Bennett T. McCallum, 2007, "Banking and Interest Rates in Monetary POlicy Analysis,” Journal of Monetary Economics, Vol. 54, No. 5, pp. 1480-1507.

Harrison, Richard, Kalin Nikolov, Meghan Quinn, Gareth Ramsay, Alasdair Scott and Ryland Thomas, 2005, “The Bank of England Quarterly Model” (London: Bank of England Publication).

IMF, 2008, "Monetary and Exchange Rate Policies in Sub-Saharan Africa,"in Regional Economic Outlook, Sub-Saharan Africa, Chapter 2. Washington, DC: IMF.

IMF, 2009(a), "Zambia: First and Second Reviews of the Three-Year Arrangement Under the Poverty Reduction and Growth Facility,'IMF Country Report No. 09/188, (Washington, DC: IMF). 
IMF, 2009(b), “The Implications of the Global Financial Crisis for Low-Income Countries,"(Washington, DC: IMF).

IMF, 2010, “Zambia: Fourth Review Under the Extended Credit Facility,”IMF Country Report No. 10/208, (Washington, DC: IMF).

Kiyotaki, Nobuhiro and John Moore, 1997, "Credit Cycles," Journal of Political Economy, Vol. 105 , pp. 211-248.

Kumhoff, Michael, Douglas Laxton, Dirk Muir and Susanna Mursula, 2010, "The Global Integrated Monetary and Fiscal Model (GIMF) Theoretical Structure ,'IMF Working Paper 10/34.

Laxton, Douglas, and Paolo Pesenti, 2003, "Monetary Policy Rules for Small, Open, Emerging Economies" Journal of Monetary Economics, Vol. 50, No. 5, pp. 1109-1146.

Mendoza, Enrique, 2006, “Lessons from the Debt-Deflation Theory of Sudden Stops,"NBER Working Paper 11966.

Mishra, Prachi, Peter Montiel and Antonio Spilimbergo A., 2010, "Monetary transmission in low-income countries,'IMF Working Paper 10/223.

Stiglitz, Joseph and Andrew Weiss, 1981, "Credit Rationing in Markets with Imperfect Information," American Economic Review, Vol. 73, No. 5, pp. 393-410.

Williamson, Stephen, 1987, "Costly Monitoring, Loan Contracts, and Equilibrium Credit Rationing," Quarterly Journal of Economics, Vol. 102, No. 1, pp. 135-145.

Woodford, Michael, 2010, "Financial Intermediation and Macroeconomic Analysis," Journal of Economic Perpectives, Vol. 24, No. 4, pp. 21-44. 


\begin{tabular}{|c|c|c|c|}
\hline \multicolumn{4}{|c|}{ Households } \\
\hline Parameter & Value & Parameter & Value \\
\hline$\beta$ & $0.97^{1 / 4}$ & $\chi$ & 0.3 \\
\hline$\psi_{c}$ & 0 & $\omega$ & 0.98 \\
\hline$\xi_{w}$ & 0.02 & $c_{1}$ & 1 \\
\hline$\varrho_{1}$ & 0.2 & $\varrho_{2}$ & 0.2 \\
\hline$P_{C}^{-} C / \bar{D}$ & 1 & & \\
\hline \multicolumn{4}{|c|}{ Firms } \\
\hline$\gamma_{N}$ & 0.50 & $\gamma_{M}$ & 0.20 \\
\hline$\delta$ & 0.02 & $\alpha$ & 0.50 \\
\hline$\xi_{c}$ & 0.03 & $\sigma_{K}$ & 1 \\
\hline$\psi_{X}$ & 60 & $\psi_{y}$ & 3 \\
\hline \multicolumn{4}{|c|}{ Banks } \\
\hline$g_{1}$ & 0.005 & $h_{1}$ & 0.02 \\
\hline $\bar{D} / \bar{H}$ & 3.49 & $\bar{F} / \overline{Y^{N}}$ & 0.60 \\
\hline$\mu_{2}$ & 0.25 & $\mu_{3}$ & 0.12 \\
\hline$\mu_{4}$ & 0.045 & $\xi_{R}$ & 0.06 \\
\hline \multicolumn{4}{|c|}{ Monetary Authority } \\
\hline$\kappa_{\pi, H}$ & 1.5 & $\kappa_{D, H}$ & 0 \\
\hline$\rho_{H}$ & 0 & & \\
\hline \multicolumn{4}{|c|}{ The Government } \\
\hline$\phi$ & 0.12 & $\tau_{G}$ & 0.1 \\
\hline$\rho_{G}$ & 0.95 & $\bar{T} / \overline{Y^{N}}$ & 0.23 \\
\hline$P_{C}^{-} G / \overline{Y^{N}}$ & 0.22 & $\overline{B^{b} k} / \overline{Y^{N}}$ & 0.60 \\
\hline
\end{tabular}

Table 1: Calibration of model parameters and steady-state ratios 


\begin{tabular}{lcclll}
\hline Monetary Policy & Neutral & Loose & $\begin{array}{l}\text { Broad Money } \\
\text { Targeting }\end{array}$ & $\begin{array}{l}\text { Credit Growth } \\
\text { Targeting }\end{array}$ & Taylor Rule \\
\hline Private Spending & 2.8 & 5.4 & 3.4 & 5.5 & 4.1 \\
Inflation & 3.0 & 6.2 & 3.3 & 7.3 & 6.1 \\
$\begin{array}{l}\text { Nominal } \\
\text { depreciation }\end{array}$ & 12.4 & 24.0 & 14.7 & 31.8 & 29.6 \\
\hline
\end{tabular}

Table 2: Model performance across alternative monetary policy responses

Each row indicates the average difference between the alternative monetary policy regime and the baseline, in percent of that variable's steady state value, in 2009.

\begin{tabular}{llll}
\hline & Target & Rev. target & Actual \\
\hline 2008Q2 & 2522 & & 2535 \\
2008Q3 & 2655 & & 2755 \\
2008Q4 & 2789 & & 3221 \\
\hline & & & \\
2009Q2 & 3151 & & 3247 \\
2009Q3 & 3333 & 3276 \\
2009Q4 & 3661 & 3821 & 3658 \\
& & & \\
\hline
\end{tabular}

Table 3: Money targets in Zambia, 2008-2009, in bn of Kwacha.

Source: IMF Staff Reports. 


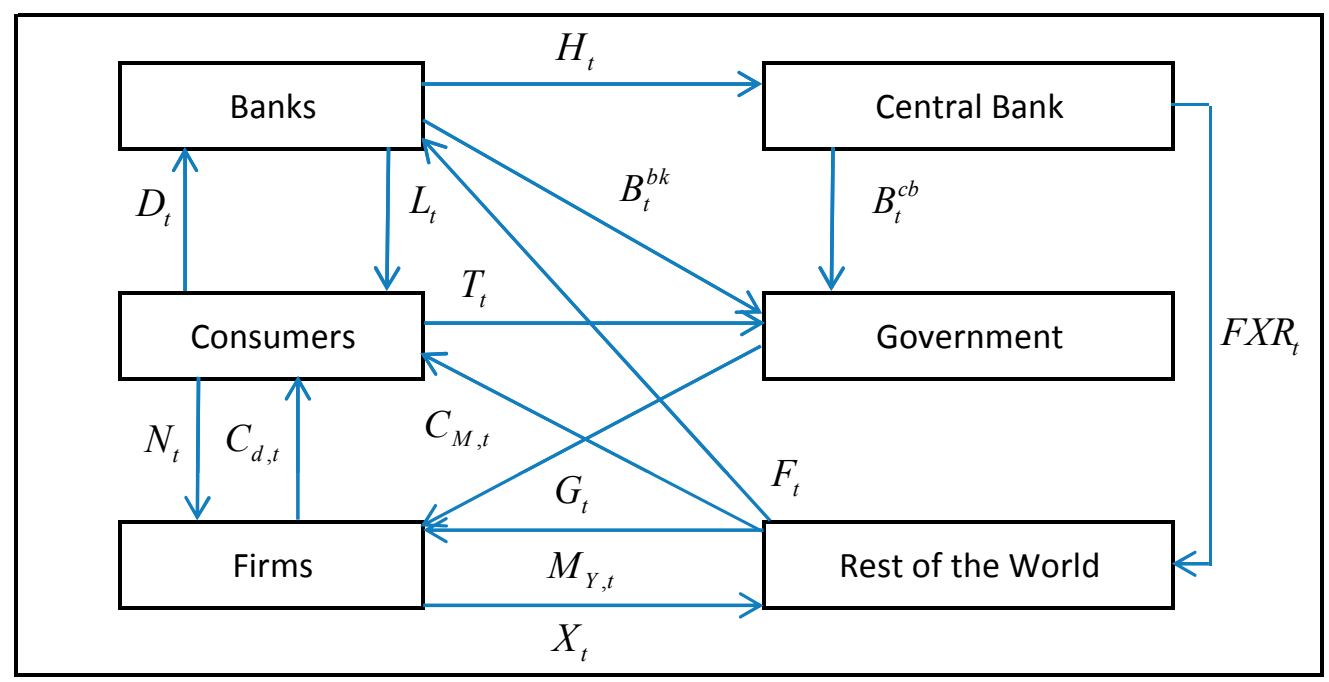

Figure 1: Model blocks 

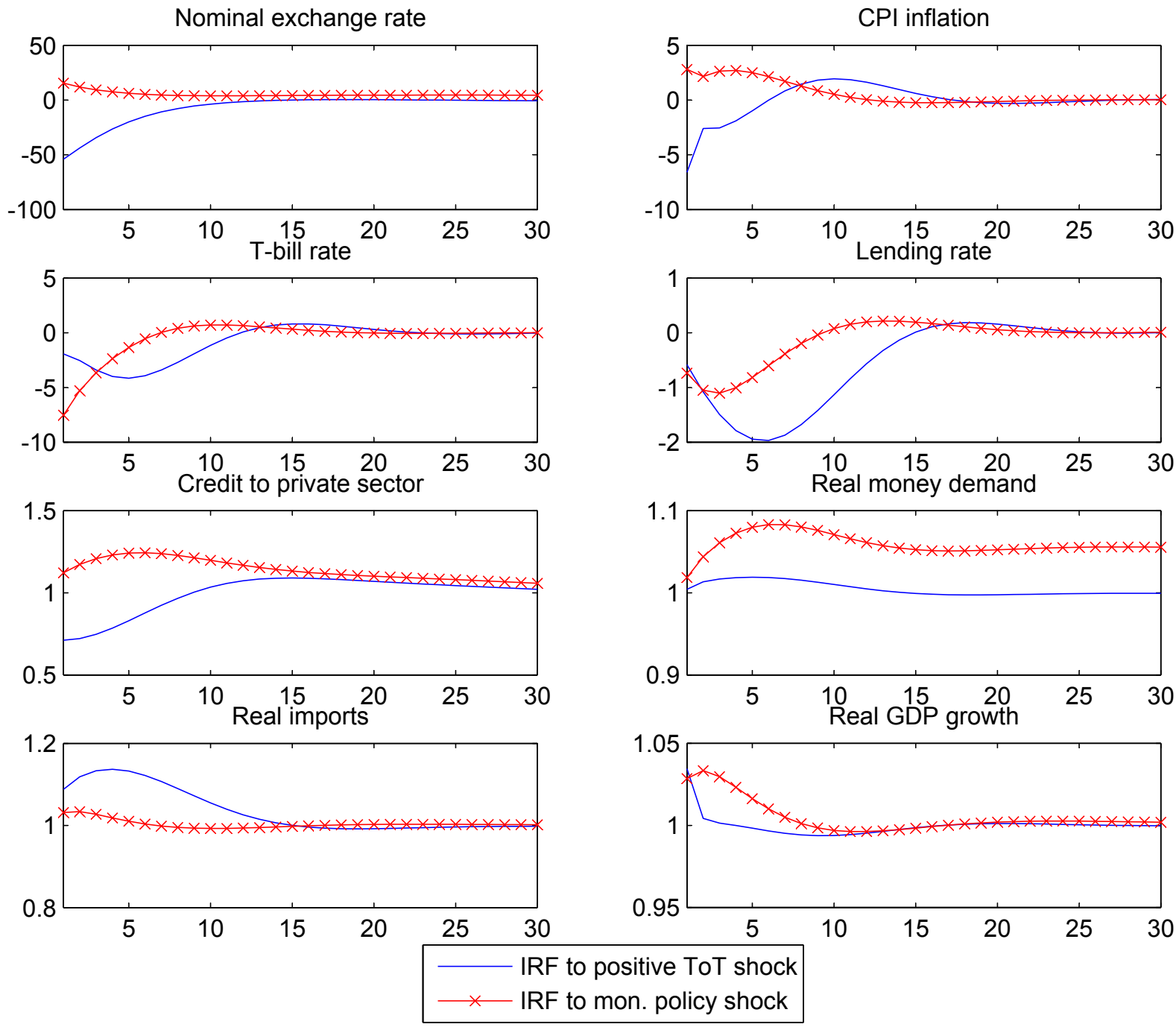

Figure 2: Impulse response functions of key variables to a terms of trade shock and a monetary policy shock. 

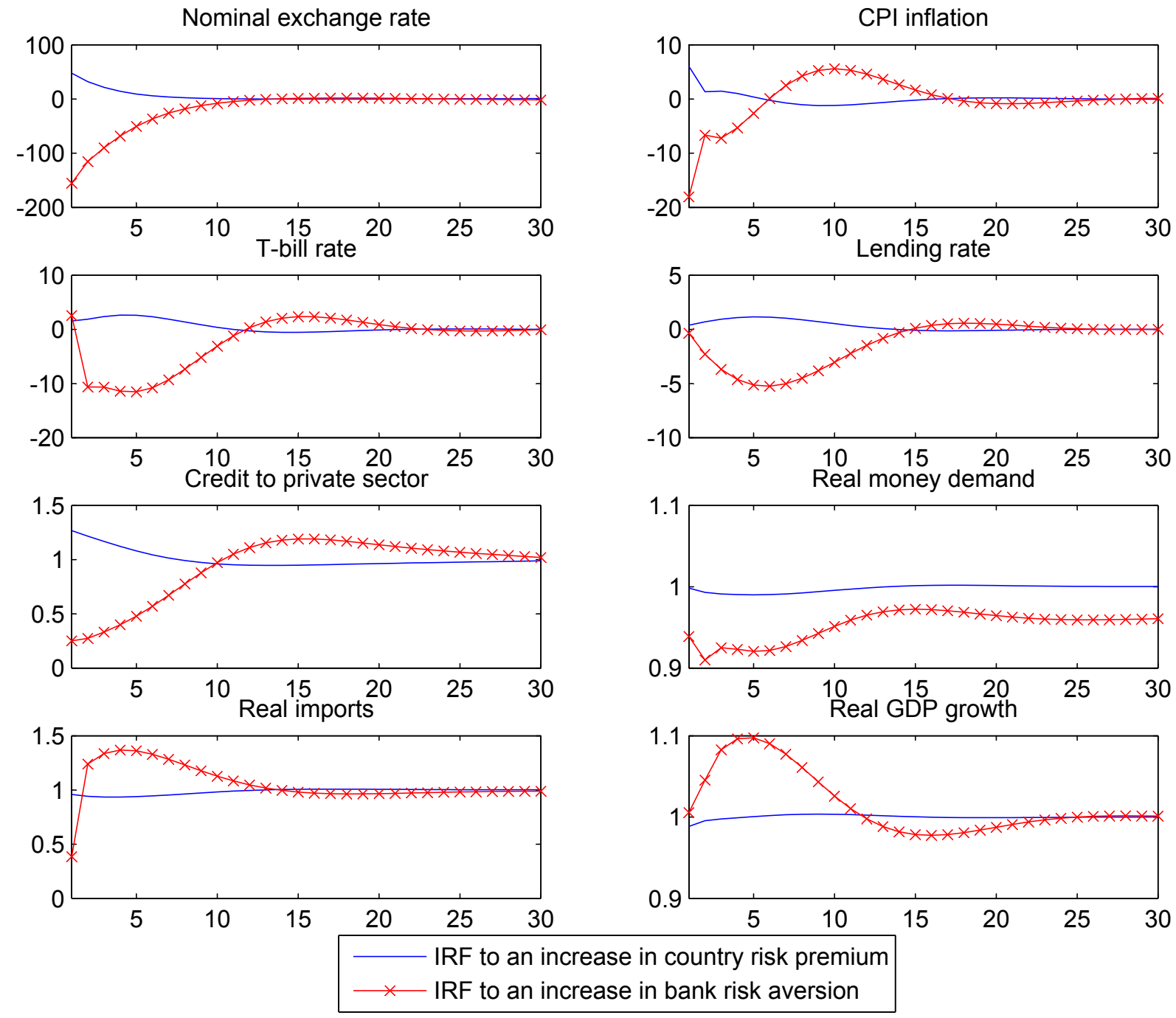

Figure 3: Impulse response functions of key variables to a risk premium shock and a banking shock. 

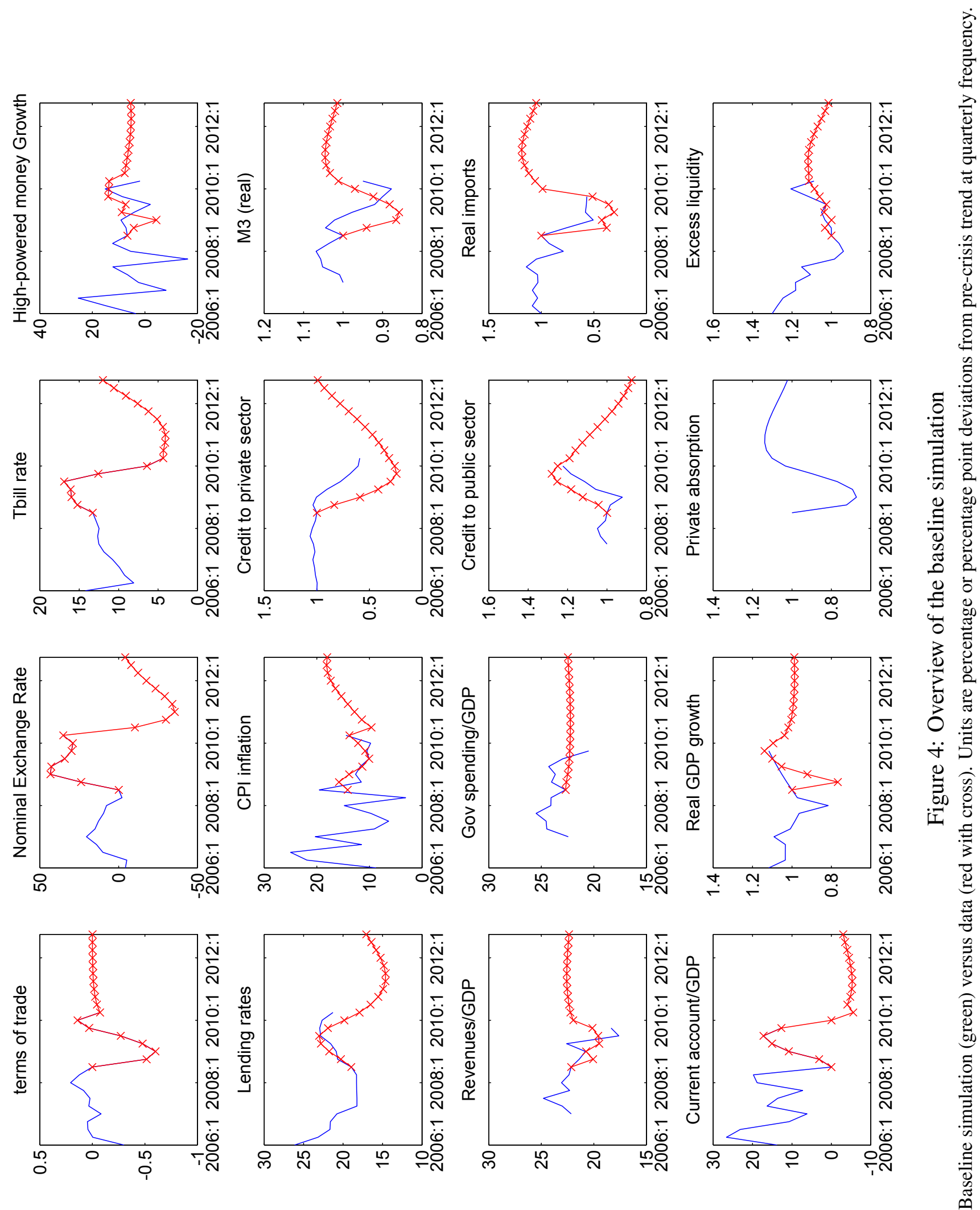


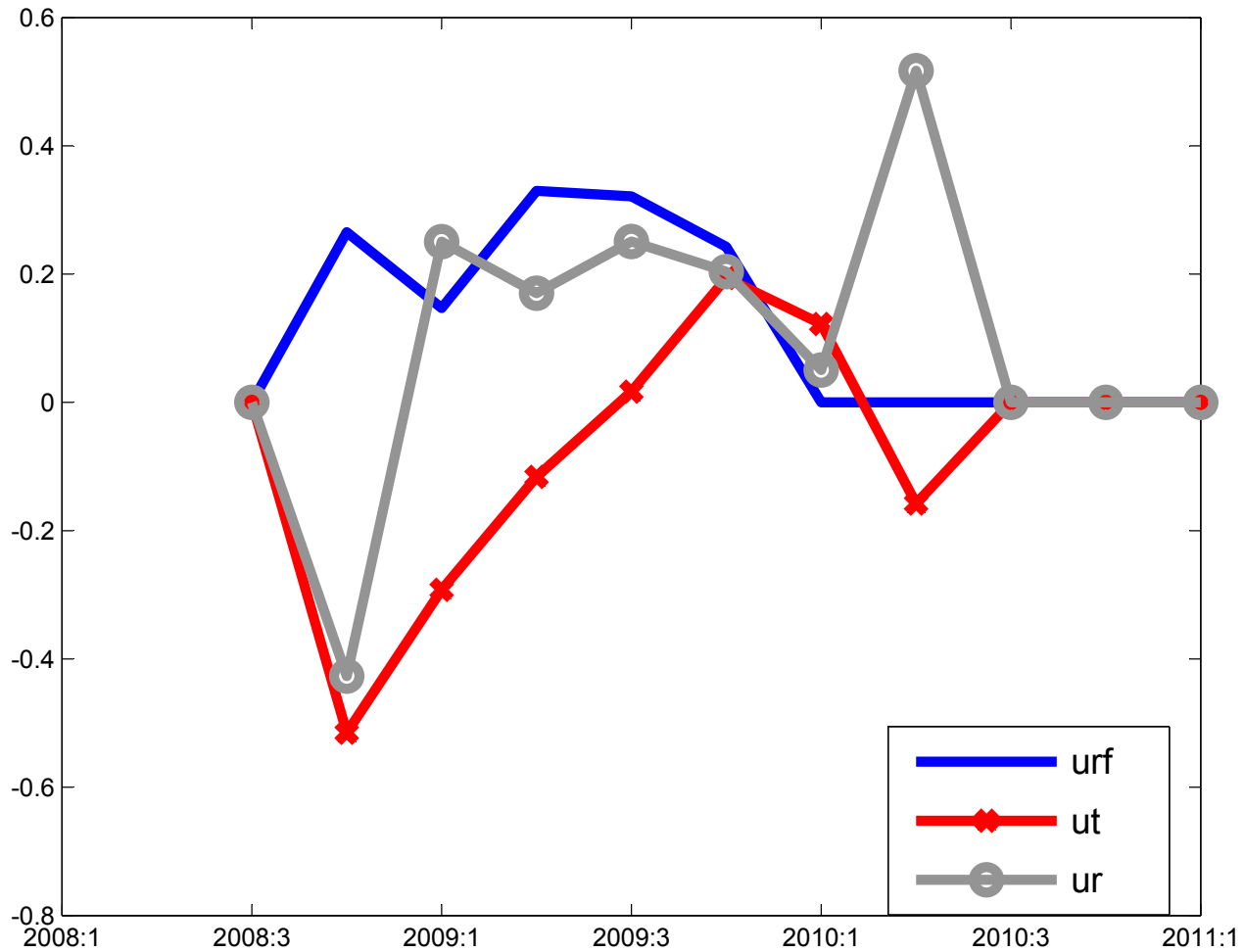

Figure 5: Tuned paths of external shocks.

Tuned path of the banking/financial shock (uf), the terms of trade shock (ut) and the country risk premium shock (ur). Units are percentage deviations from pre-crisis steady state at quarterly frequency. 

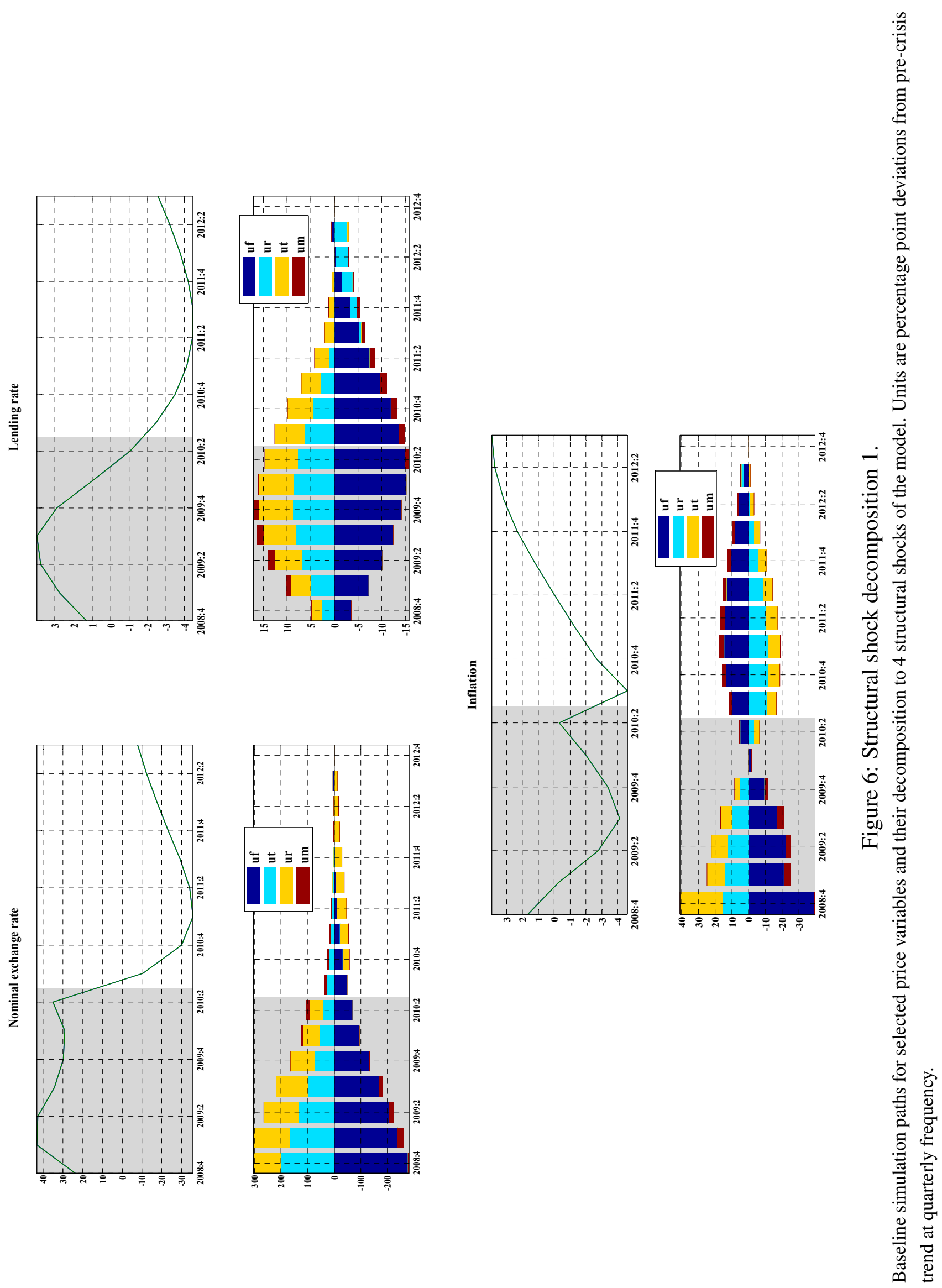

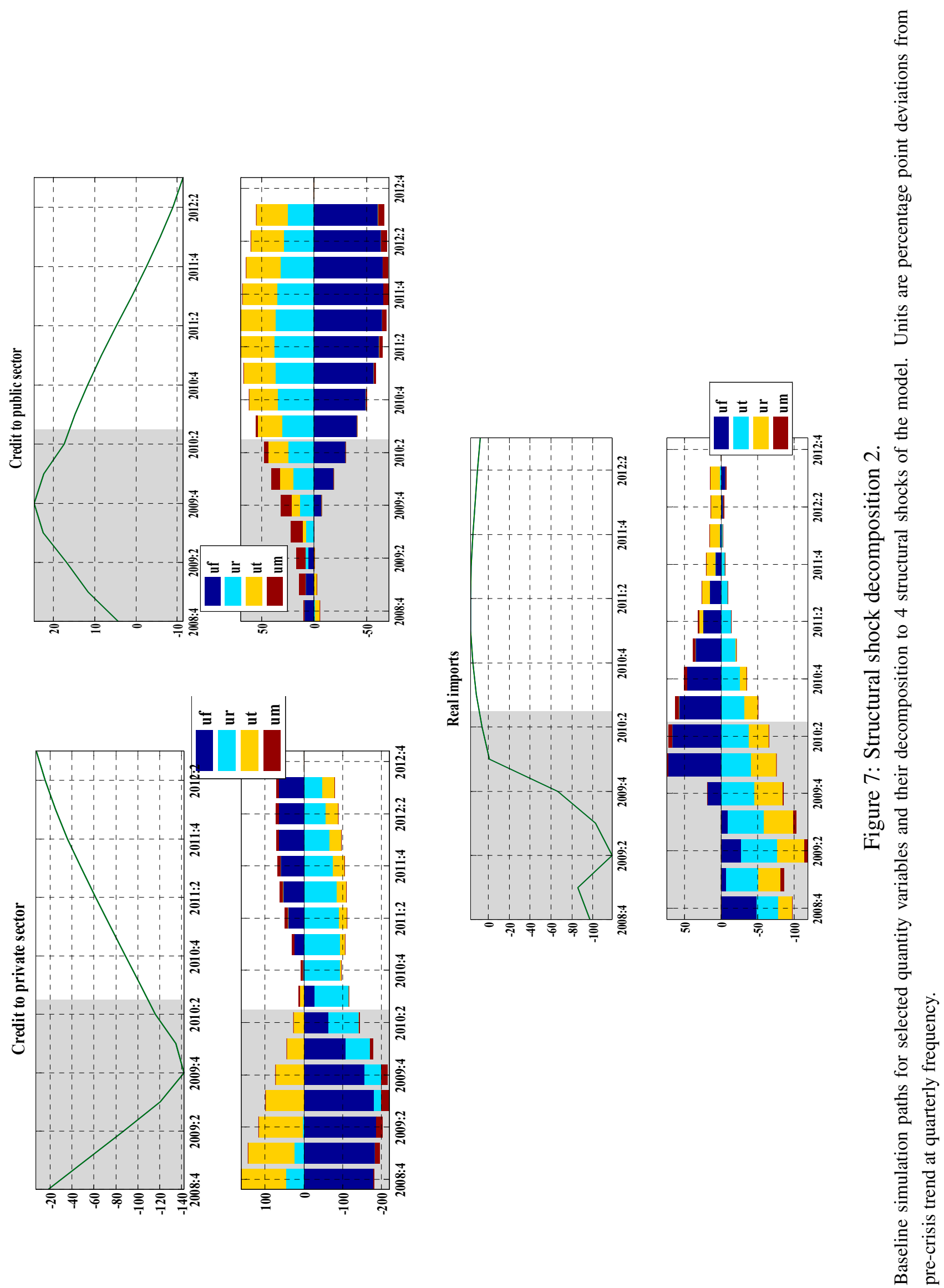

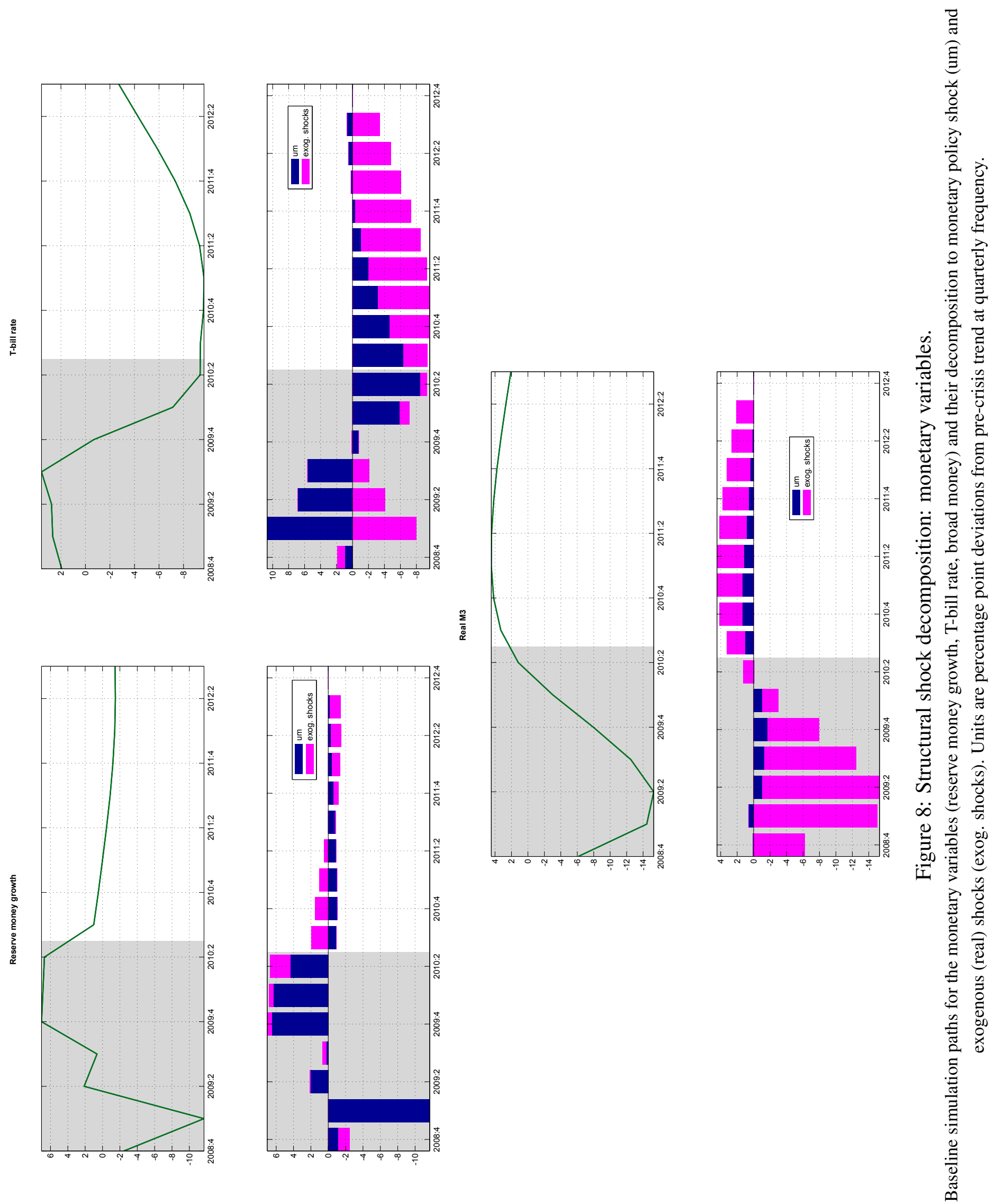

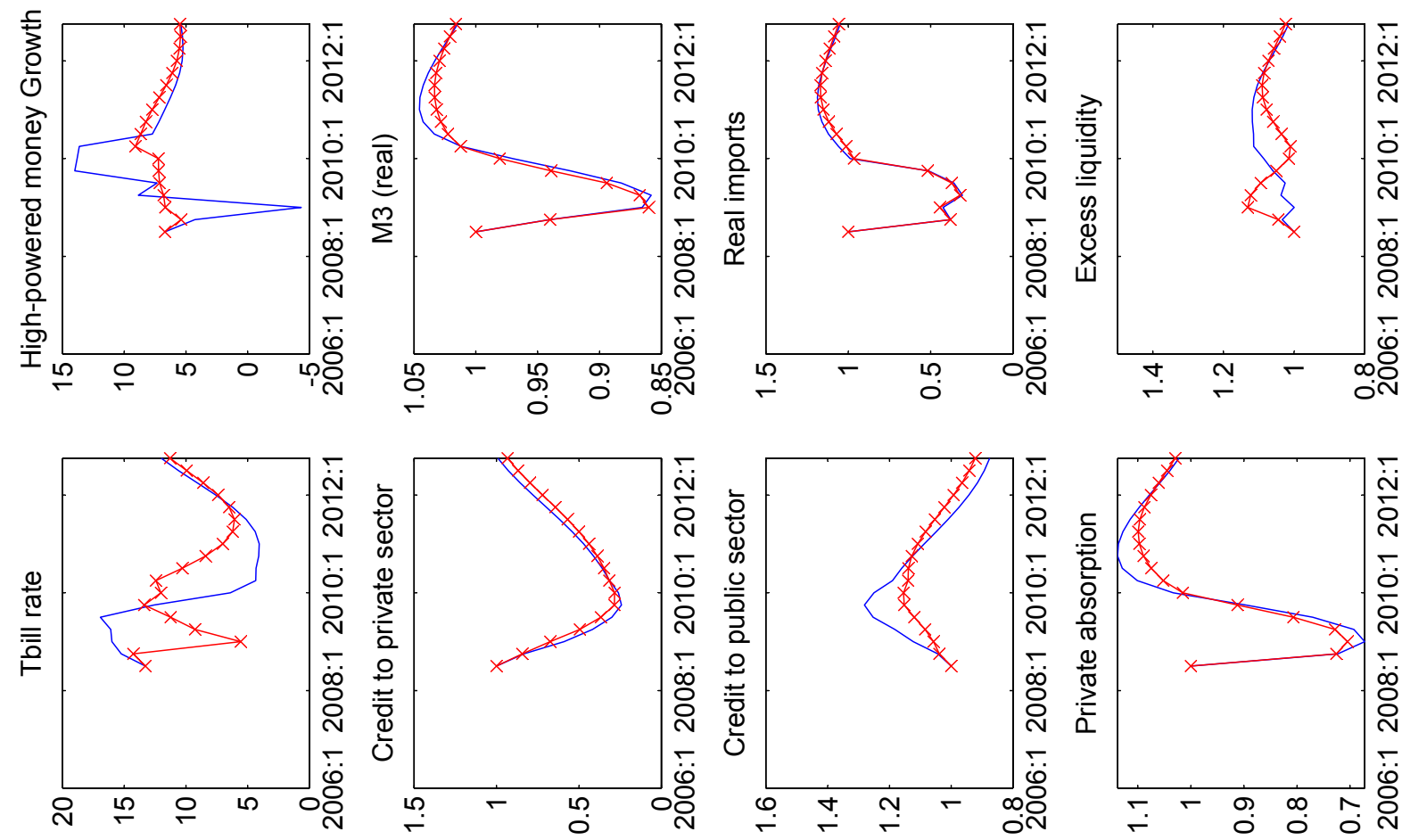

这
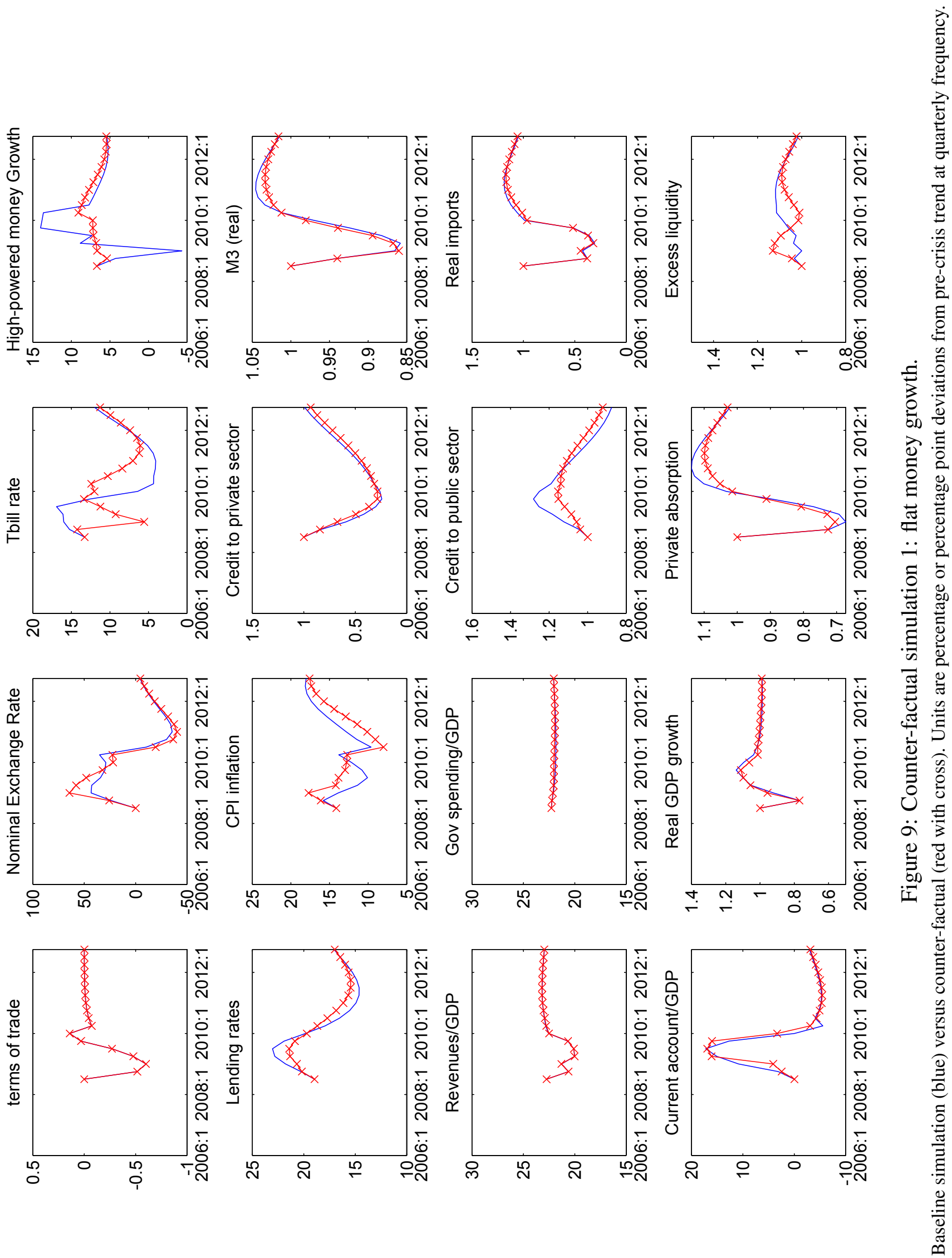

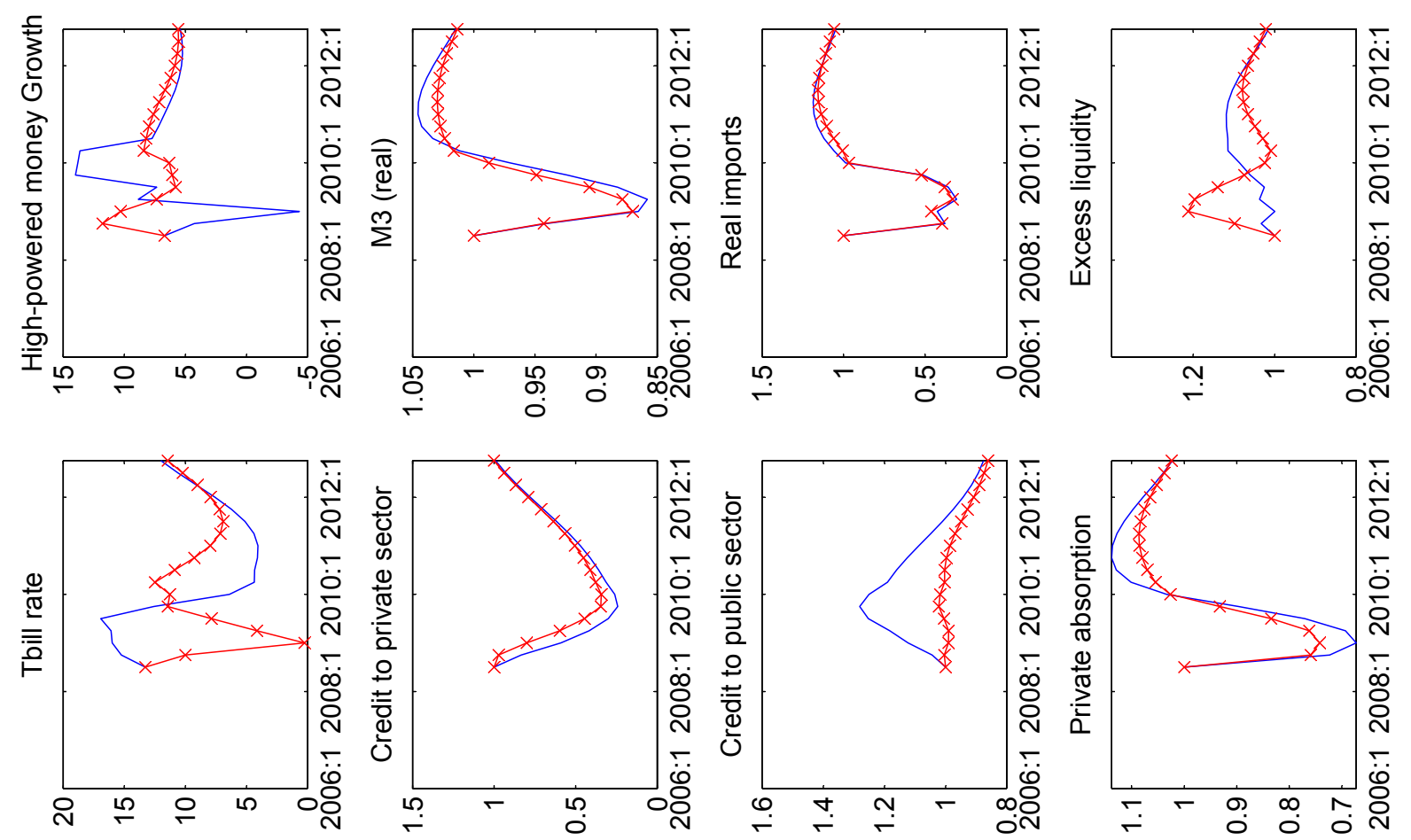

它
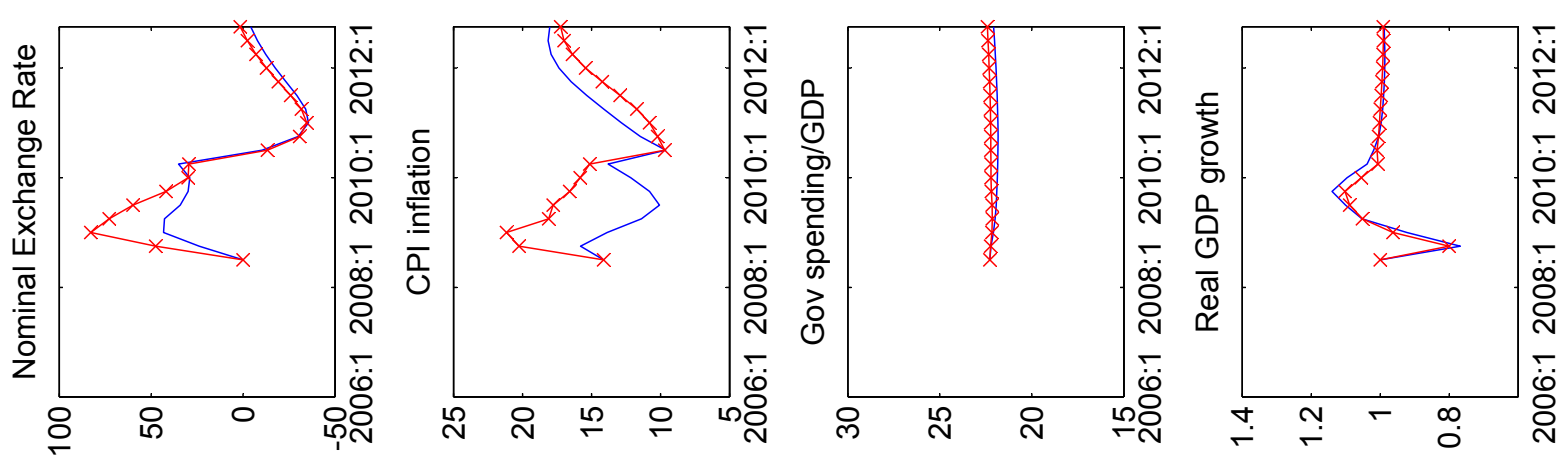

胥

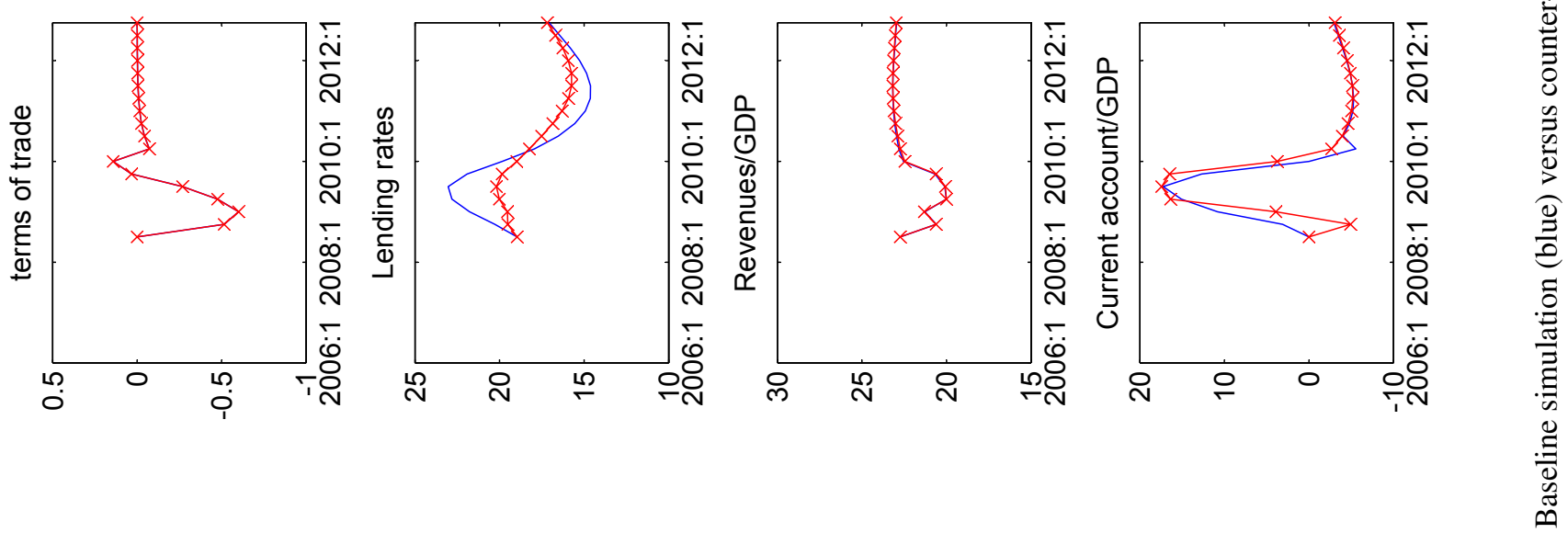


T-bill rate
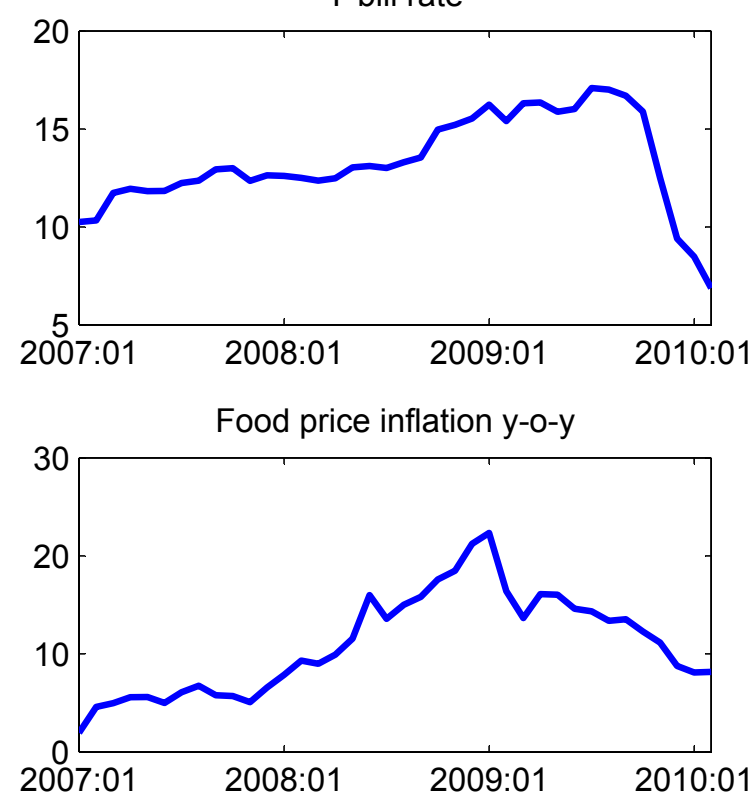

Nominal exchange rate: Kwacha/USD

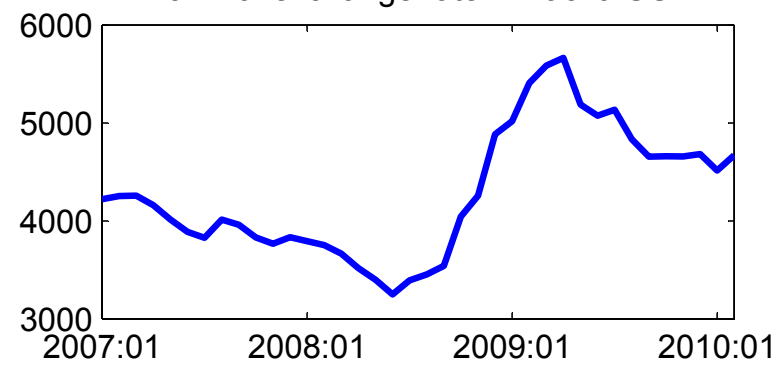

Headline inflation y-o-y
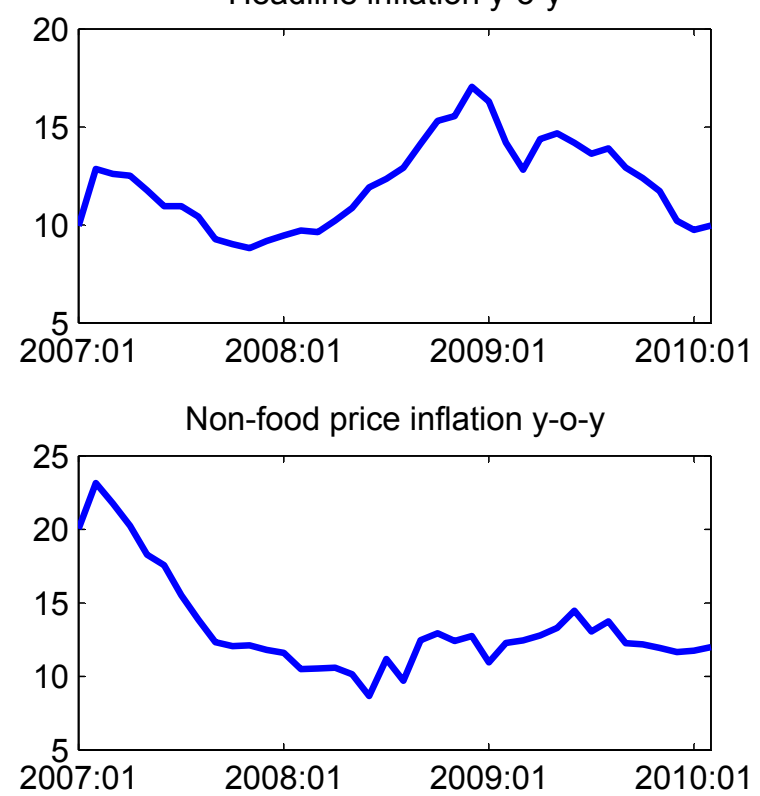

Excess liquidity: $\mathrm{H} / \mathrm{M} 3$

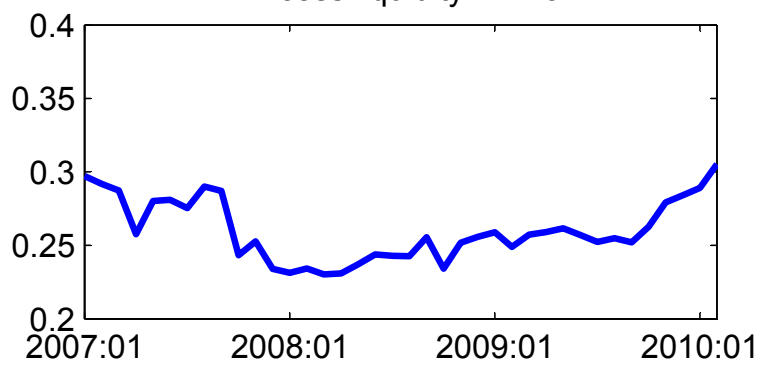

Figure 11: Key monetary variables prior to and during the crisis. 